
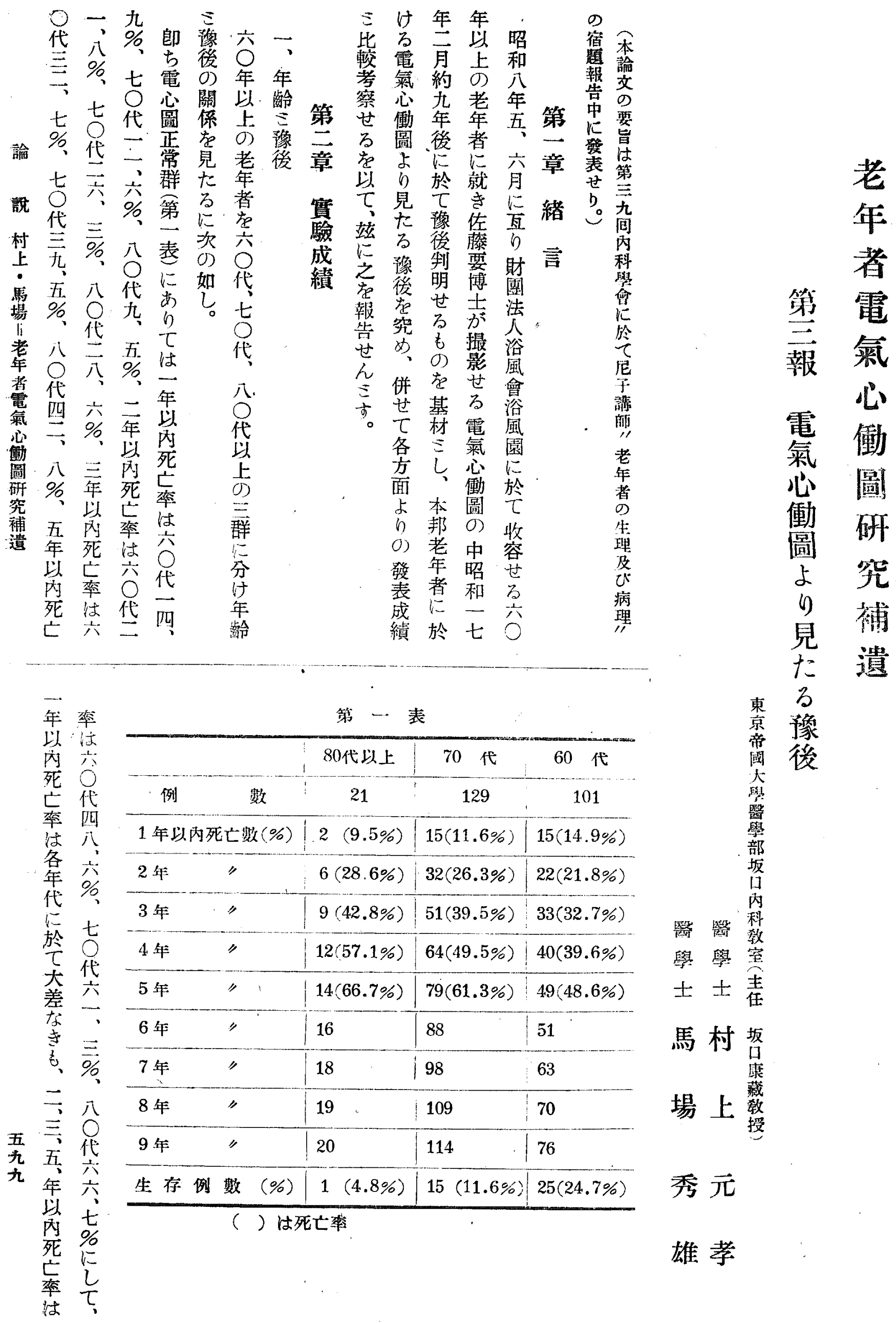


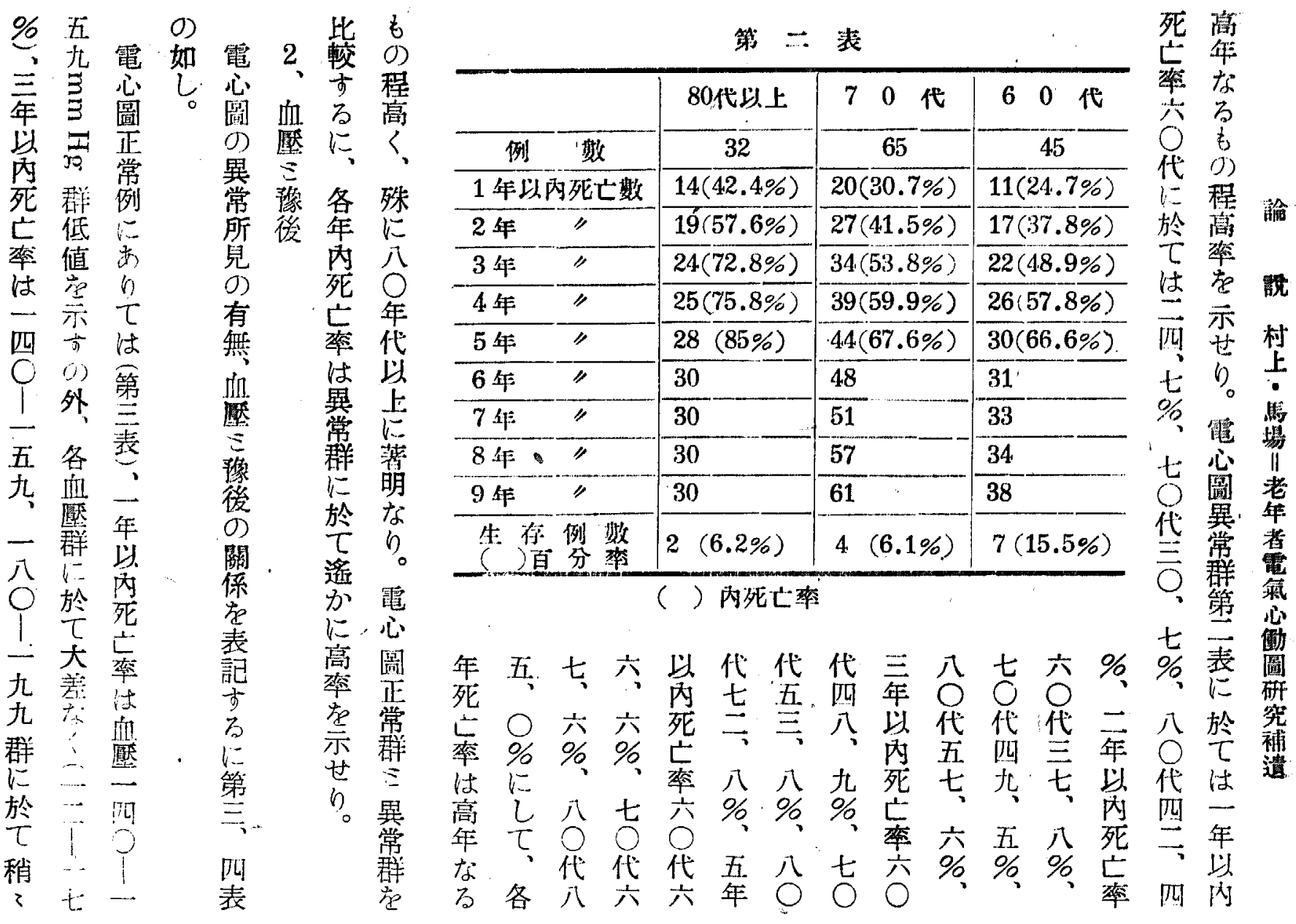

第 三表

\begin{tabular}{|c|c|c|c|c|c|c|c|}
\hline 血 & 霖 & $139 \mathrm{~mm}$ 以下 & $140 \sim 159$ & $160 \sim 179$ & $180 \sim 199$ & $200 \sim 219$ & $220 \mathrm{~mm}$ 以上: \\
\hline 例 & 数 & 58 & 54 & 41 & 36 & 33 & 21 \\
\hline 1 年以 & 死亡数 & $10(17.2 \%)$ & $3(5.5 \%)$ & $5(12.2 \%)$ & $5(13.9 \%)$ & $4(12.1 \%)$ & $3(14.3 \%)$ \\
\hline 2年 & $"$ & $-19(32.8 \%)$ & $4(7.4 \%)$ & $9(21.9 \%)$ & $7(19.4 \%)$ & $10(30.2 \%)$ & $7(33.3 \%)$ \\
\hline 3 年 & $"$ & $25(43.1 \%)$ & $11(20.4 \%)$ & $17(41.4 \%)$ & $11(30.5 \%)$ & $13(39.4 \%)$ & $12(57.1 \%)$ \\
\hline 4 年 & $"$ & $28(48.3 \%)$ & $23(42.6 \%)$ & $20(48.8 \%)$ & $15(4.1 .7 \%)$ & $15(45.4 \%)$ & $14(66.7 \%)$ \\
\hline 5 年 & $"$ & $33(56.9 \%)$ & $31(57.3 \%)$ & $25(61.0 \%)$ & $18(50.0 \%)$ & $19(57.5 \%)$ & $17(80.9 \%)$ \\
\hline 6 年 & $"$ & 36 & 32 & 26 & 22 & 19 & 17 \\
\hline 7 年 & $"$ & 44 & 34 & 31 & 25 & 23 & 19 \\
\hline 8 年 & $"$ & 49 & 37 & 34 & 28 & 27 & 20 \\
\hline 9 年 & " & 52 & 41 & 34 & 30 & 29 & 20 \\
\hline 生 & $1-3 x$ & $6(10.4 \%)$ & $13(24.0 \%)$ & $7(17.0 \%)$ & $6(16.6 \%)$ & $4 .(12.1 \%)$ & $1(4.8 \%)$ \\
\hline
\end{tabular}

低

値

整

ᄂ

卷

四

$\%$

$\underline{\bar{O}}$

五

(）內 死亡率

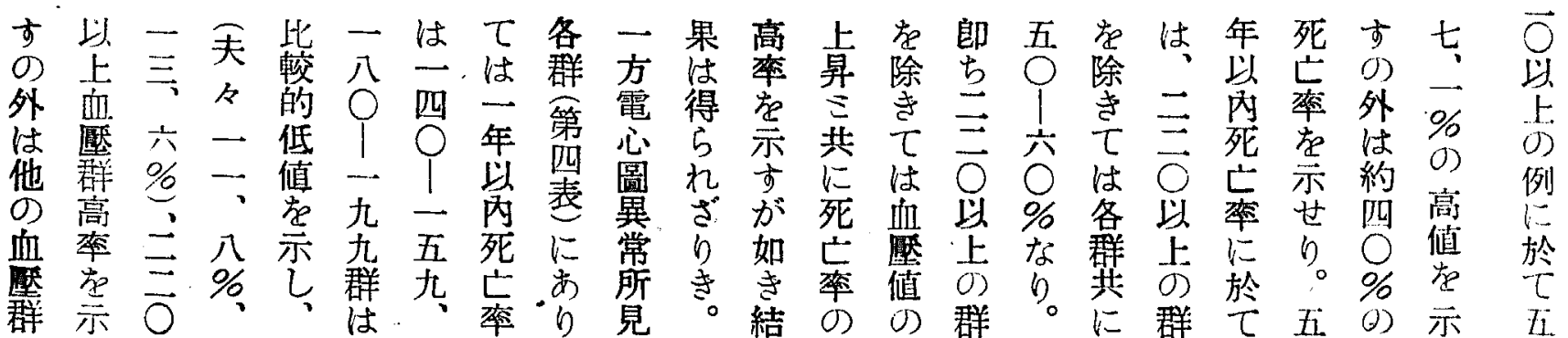


第 四表

は

\begin{tabular}{|c|c|c|c|c|c|c|c|}
\hline 血 & 厴 & 139 以下 & $140-159$ & $160 \sim 179$ & $180 \sim 199$ & $200 \sim 219$ & 220 以上 \\
\hline 例 & 數 & 21 & 17 & 37 & 22 & 23 & 25 \\
\hline \multicolumn{2}{|c|}{1 年以內死亡數 } & $6(28.6 \%)$ & $2(11.8 \%)$ & $14(37.9 \%)$ & $3(13.6 \%)$ & $8(34.8 \%)$ & $11(44.090)$ \\
\hline 2年 & $"$ & $7(33.3 \%)$ & $4(23.5 \%)$ & $18(48.6 \%)$ & $6(27.3 \%)$ & $11(47.8 \%)$ & $16(64.0 \%)$ \\
\hline 3年 & $"$ & $12(57.1 \%)$ & $5(29.4 \%)$ & $22(59.5 \%)$ & $8(36.4 \%)$ & $13(56.5 \%)$ & $20(80.0 \%$ \\
\hline 4年 & $"$ & $13(61.9 \%)$ & $5(29.4 \%)$ & $24(64.9 \%)$ & $12(54.5 \%)$ & $15(65.1 \%)$ & $21(81.0 \%$ \\
\hline 5 年 & " & $16(76.1 \%)$ & $9(52.9 \%)$ & $27(73.0 \%)$ & $13(59.1 \%)$ & $16(69.6 \%)$ & $21(84.0 \%)$ \\
\hline 6 年 & $"$ & 17 & 12 & 28 & 15 & 17 & 21 \\
\hline 7 年 & " & 17 & 13 & 30 & 16 & 18 & 22 \\
\hline 8 年 & $"$ & 18 & 14 & 32 & 17 & 19 & 23 \\
\hline 9 年 & $"$ & 19 & 15 & 34 & 18 & 21 & 23 \\
\hline 生 & 例 数 & $2(9.5 \%)$ & $2(16.8 \%)$ & $3(8.1 \%)$ & $4(18.2 \%)$ & $2(8.7 \%)$ & $1(4.00$ \\
\hline
\end{tabular}

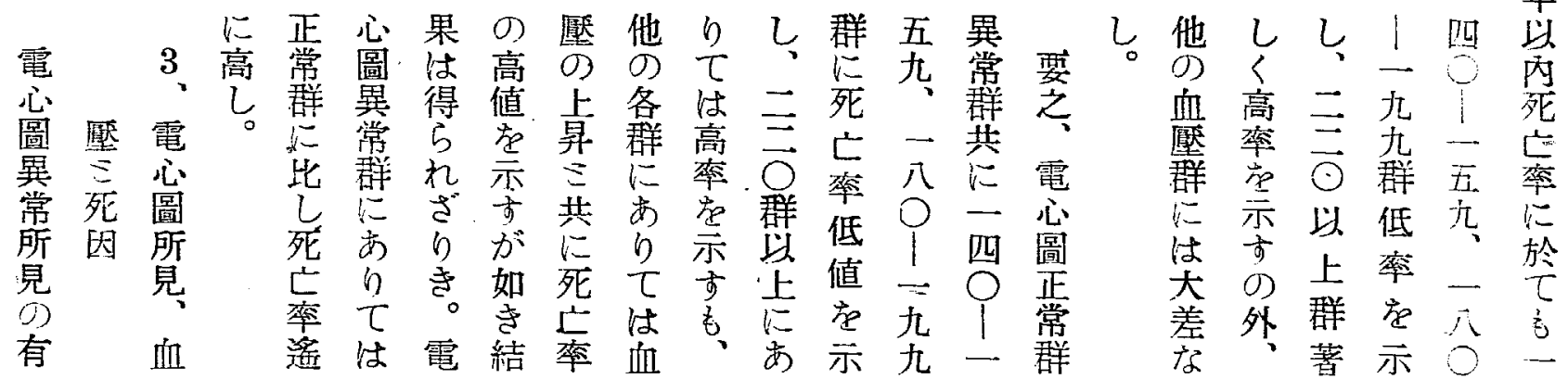

第五表 電心圖正常群死因統計

\begin{tabular}{|c|c|c|c|c|c|c|c|}
\hline 血 & 139 以下 & $140 \sim 159$ & $160 \sim 179$ & $180 \sim 199$ & $200 \sim 219$ & 220 以上 & 計 \\
\hline 冽 & 55 & 40 & 32 & 34 & 27 & 18 & 206 \\
\hline 咨 & $27.3 \%$ & $17.5 \%$ & $34.4 \%$ & $26.4 \%$ & $25.9 \%$ & $33.3 \%$ & $24.2 \%$ \\
\hline 心 衰 弱 & $14.5 \%$ & $30.0 \%$ & $12.5 \%$ & $14.7 \%$ & $22.2 \%$ & $11.1 \%$ & $17.9 \%$ \\
\hline 儆 溶 血 & $5.5 \%$ & $2.5 \%$ & $6.2 \%$ & $8.8 \%$ & $3.7 \%$ & $27.8 \%$ & $7.3 \%$ \\
\hline 憏軟化症 & 0 & 0 & $3.1 \%$ & 0 & $3.7 \%$ & 0 & $0.9 \%$ \\
\hline 肺 結 核 & $12.7 \%$ & $2.5 \%$ & $3.1 \%$ & $2.9 \%$ & $7.4 \%$ & $\overline{0}$ & $6.3 \%$ \\
\hline 唅性疾患 & $3.6 \%$ & $5.0 \%$ & $6.2 \%$ & $5.9 \%$ & $7.4 \%$ & $5.6 \%$ & $5.3 \%$ \\
\hline 敗 血 症 & $3.6 \%$ & 0 & $3.1 \%$ & 0 & 0 & 0 & $1.5 \%$ \\
\hline 急性大腸炎 & $9.1 \%$ & $22.5 \%$ & $12.5 \%$ & $8.8 \%$ & $14.8 \%$ & $11.1 \%$ & $13.50^{\circ}$ \\
\hline
\end{tabular}

○が係

5 万 $\stackrel{\mathrm{S}}{\mathrm{s}}=$

$\mathrm{m}$ 誘 $\mathrm{T}$ 括 電

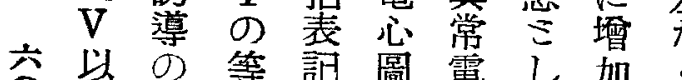

○卡 電古所

のの位る見

も专線に心

のの下第辣見鹳

は大

除にの表导

外七低のの 徐

せは市.如關

類 て 間如它腦市心心腦

\section{士 弱}

賞

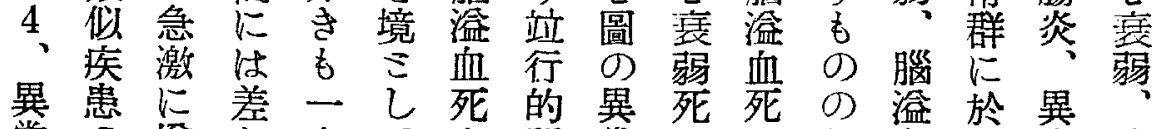


第六表 電心圖異常群死因統計

T

\begin{tabular}{|c|c|c|c|c|c|c|c|}
\hline 監 & 139以下 & $140 \sim 159$ & $160 \sim 179$ & $180 \sim 199$ & $200 \sim 219$ & 200 以上 & 計 \\
\hline 數 & 18 & 14 & 29 & 17 & 24 & 18 & 120 \\
\hline 炎 & $38.9 \%$ & $42.8 \%$ & $10.3 \%$ & $17.6 \%$ & $20.8 \%$ & $16.7 \%$ & $22.5 \%$ \\
\hline 心衰 弱 & $16.7 \%$ & $21.4 \%$ & $34.5 \%$ & $23.5 \%$ & $4.2 \%$ & $22.2 \%$ & $20.0 \%$ \\
\hline 满溢血 & $5.6 \%$ & 0 & $17.2 \%$ & $11.8 \%$ & $8.3 \%$ & $33.3 \%$ & $13.3 \%$ \\
\hline 腦軟化症 & 0 & 0 & 0 & 0 & $8.3 \%$ & $16.7 \%$ & $4.2 \%$ \\
\hline 肺結核 & $5.6 \%$ & 0 & $6.9 \%$ & 0 & 0 & 0 & $2.5 \%$ \\
\hline 癌性疾患 & 0 & $21.4 \%$ & 0 & 0 & $16.7 \%$ & 0 & $5.8 \%$ \\
\hline 敗血 症 & $5.6 \%$ & $14.3 \%$ & $10.3 \%$ & 0 & $8.3 \%$ & $5.6 \%$ & $7.5 \%$ \\
\hline 急性大腸炎 & $5.6 \%$ & 0 & $10.3 \%$ & $23.5 \%$ & 0 & $5.6 \%$ & $7.5 \%$ \\
\hline
\end{tabular}

の 不

陰 二

性 そ

第 萻

㐿 上

誘 賎

に资村

於示上

せ 馬

るる場

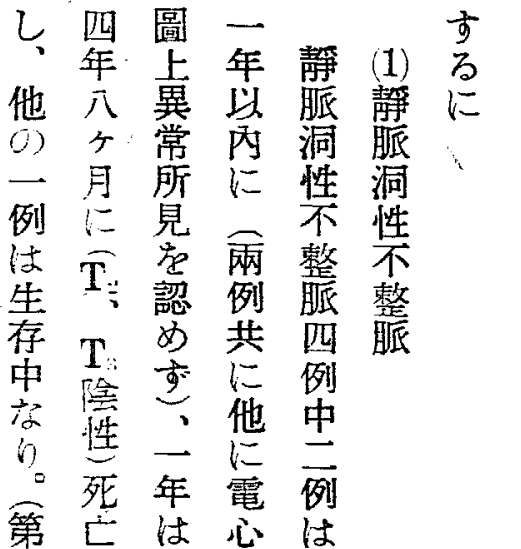

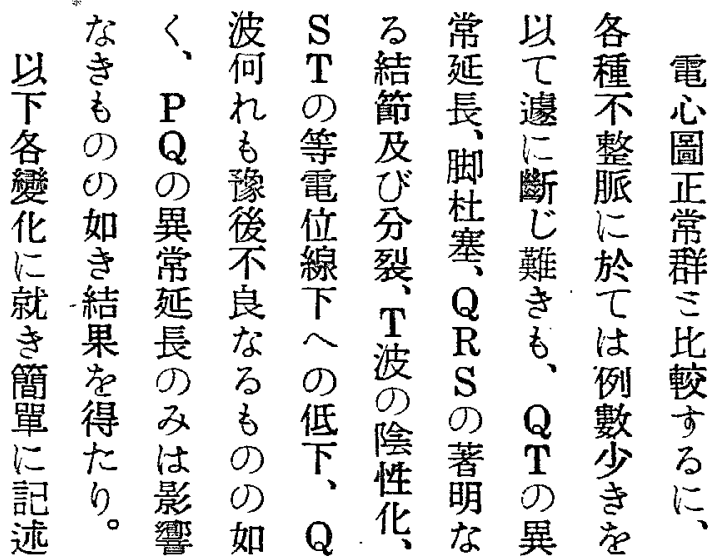

の $\bigcirc な$

第 七 表

\begin{tabular}{|c|c|c|c|c|c|c|c|c|c|c|c|}
\hline & 數 & 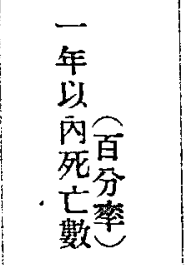 & 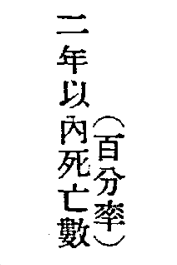 & 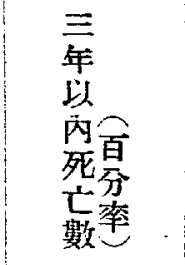 & 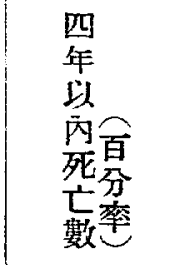 & 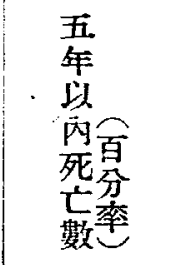 & 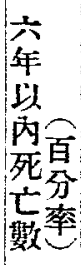 & 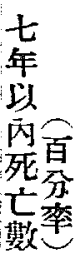 & $\begin{array}{l}\text { 入 } \\
\text { 年 } \\
\text { 以 } \\
\text { 离面 } \\
\text { 穷率 }\end{array}$ & 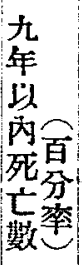 & $\begin{array}{l}\text { 生 } \\
\text { 存 } \\
\text { 例夏 } \\
\text { 數率 }\end{array}$ \\
\hline 群 & 251 & $32(12.7 \%)$ & $60(23.9 \%)$ & $93(37.1 \%)$ & $116(46.2 \%)$ & $142(56.6 \%)$ & 149 & $\overline{179}$ & $\overline{199}$ & 210 & $\overline{4(16.3 \%)}$ \\
\hline 静脈洞性不整脈 & 4 & 2 & 2 & 2 & 2 & 3 & 3 & 3 & 3 & 3 & 1 \\
\hline 絕對性不整脈 & 2 & 1 & 1 & 2 & & & & & & & \\
\hline 前厚性期外收縮 & 8 & 3 & 5 & 5 & 7 & & & & & & \\
\hline 心室性期外收縮 & 13 & 4 & 5 & 7 & 7 & 8 & 9 & 9 & 9 & 11 & 2 \\
\hline P Q-延 & 29 & $5(17.2 \%)$ & $8(27.6 \%)$ & $15(51.7 \%)$ & 15 & $19(65.5 \%)$ & 23 & 25 & 27 & 27 & $2(6.9 \%)$ \\
\hline Q T-延 & $\overline{52}$ & $17(32.7 \%)$ & $28(53,8 \%)$ & $32(61.4 \%)$ & $34(65.3 \%)$ & $37(71.1 \%)$ & 38 & 39 & 42 & 47 & $5(9.6 \%)$ \\
\hline 塞 & 4 & 2 & 3 & 3 & 3 & 3 & 3 & 3 & 3 & 4 & \\
\hline $\begin{array}{l}\text { QRS群の著明な } \\
\text { 万結節及分裂 }\end{array}$ & 33 & $\mid 10(30.3 \%)$ & $14(42.4 \%)$ & $20(60.6 \%)$ & $24(72.7 \%)$ & $28(84.8 \%)$ & 29 & 30 & 31 & 31 & $2(6.1 \%)$ \\
\hline 性 & 16 & $3(18.7 \%)$ & $6(37.5 \%)$ & $7(43.7 \%)$ & $11(68.7 \%)$ & 12 & 12 & 13 & 15 & 16 & \\
\hline $\mathrm{ST}$ 㓌 & 36 & $9(25.0 \%)$ & $15(41.6 \%)$ & $20(55.5 \%)$ & $22(61.1 \%)$ & $25(69.4 \%)$ & 25 & 26 & 28 & 31 & 5 \\
\hline ST. T O 變 化 & 20 & $13(65.0 \%)$ & $14(70.0 \%)$ & $15(75.0 \%)$ & 15 & 16 & 16 & 17 & 17 & 19 & 1 \\
\hline $\mathrm{Q}_{3}$ & 8 & 4 & 6 & 7 & 7 & 8 & & & & & \\
\hline
\end{tabular}




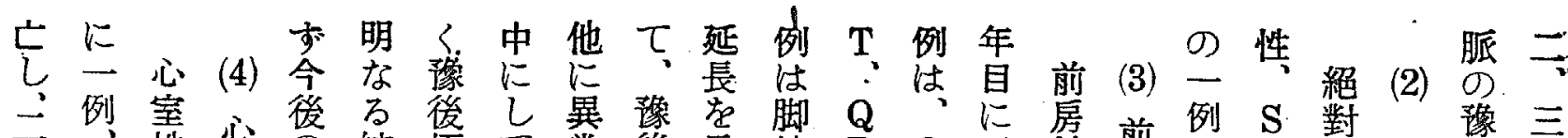

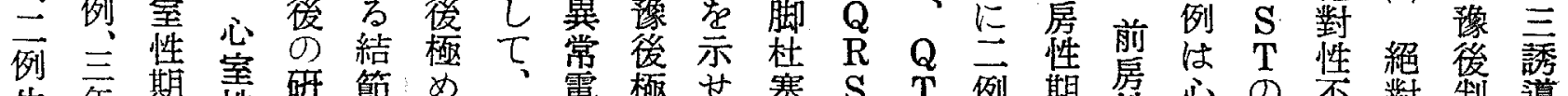
生 年 期 室 研節:

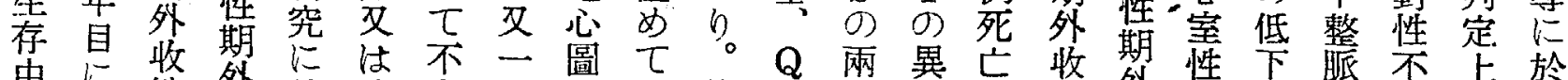

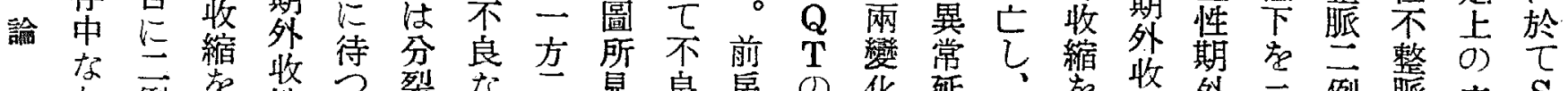

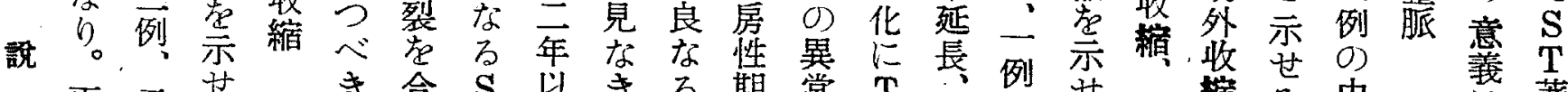

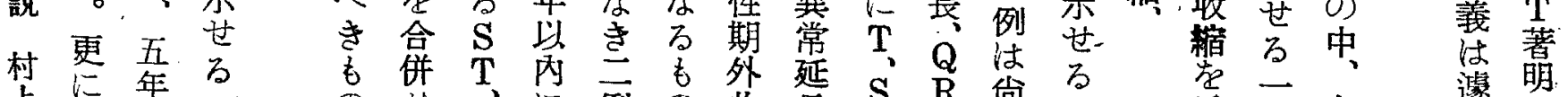
上心年る

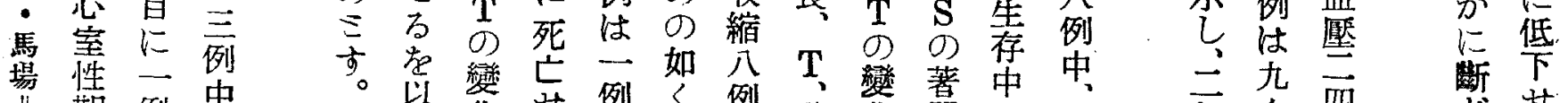

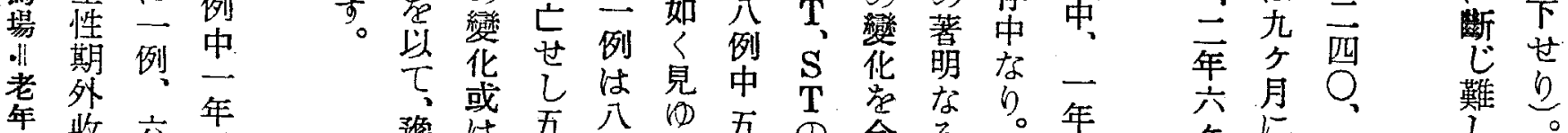
暒電縮 年 岗

電繶自丙

働にに死

圆例 せ

究医学

遭貺年四

所是例

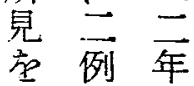

認死 目

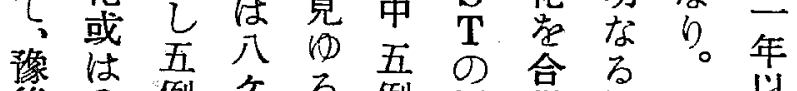

後 $\mathbf{Q}$ 例与古例變併結一只

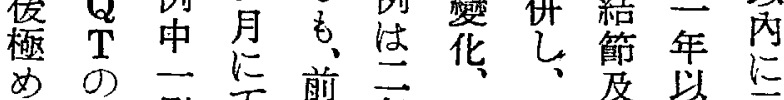

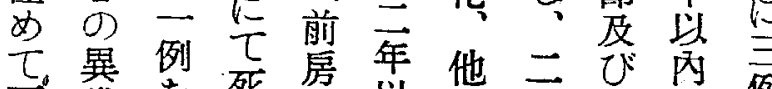

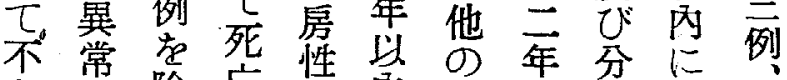

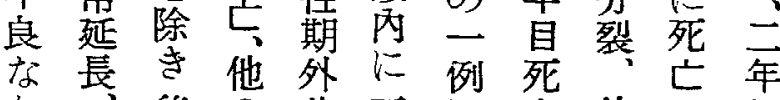

b後の收死 仗亡他を目

$\leq \mathrm{Q}$ 述一縮 亡 $\mathrm{Q}$ の のしに

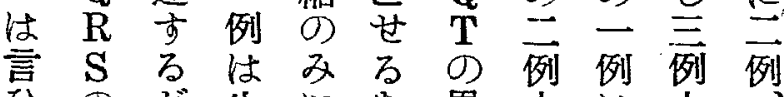

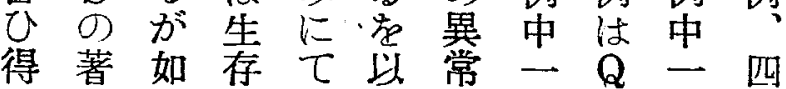

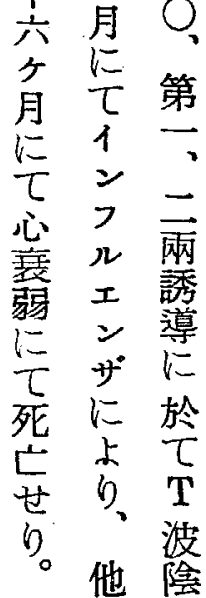

難

例

數

き

些

靜

脈

性

整

吕 吕 III 兵吾疮ち 度度

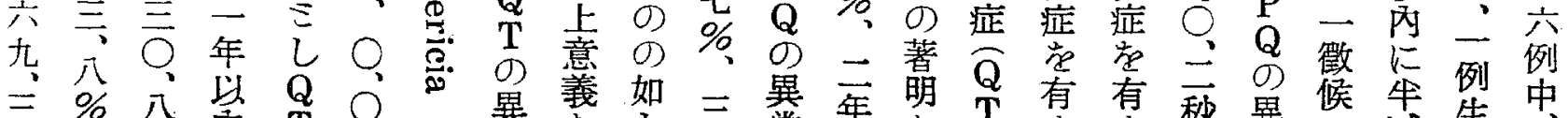

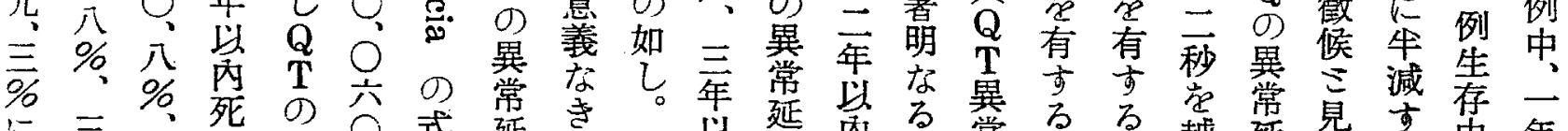

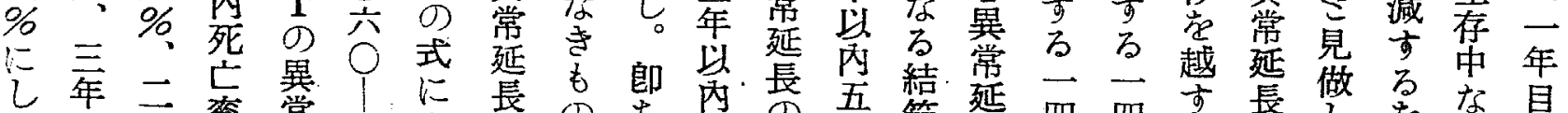

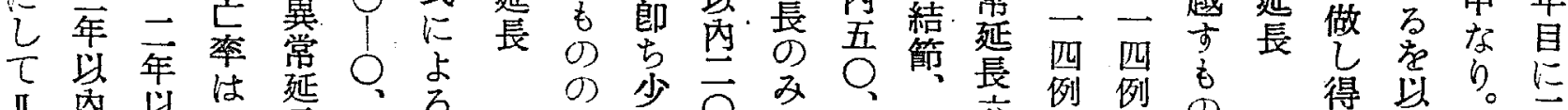
II 离

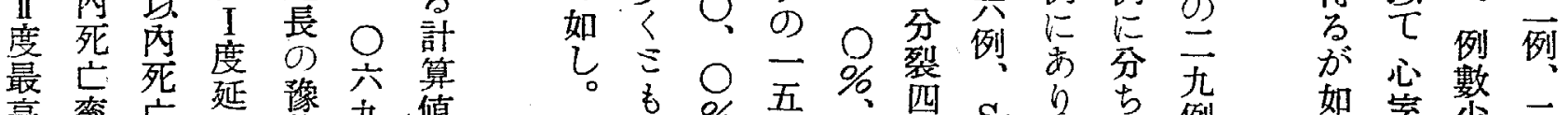

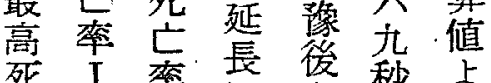
死 I 率左乾秒よ

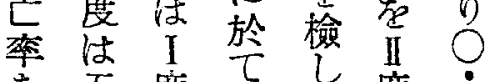
宗五度はたた度它

六咅三百，西 六度 $\%$ 应 度 度 II

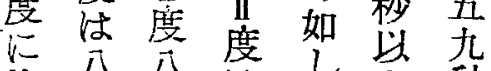

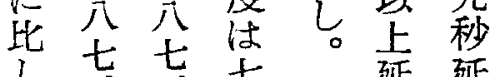

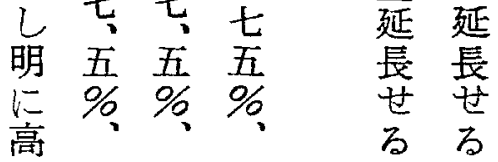

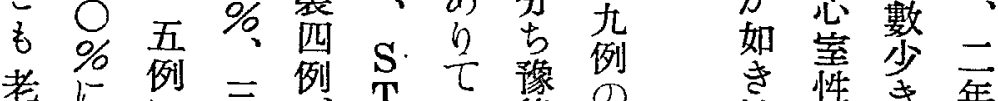
老に烈

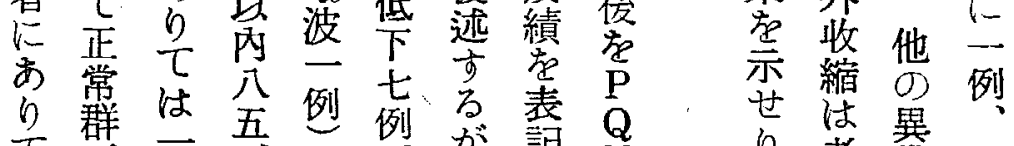

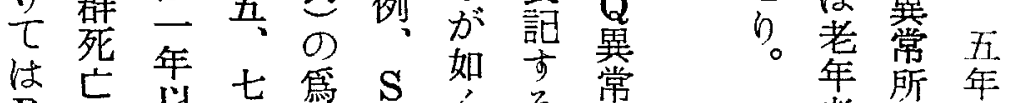

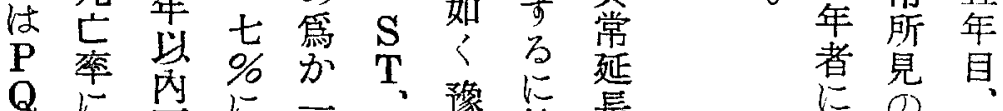

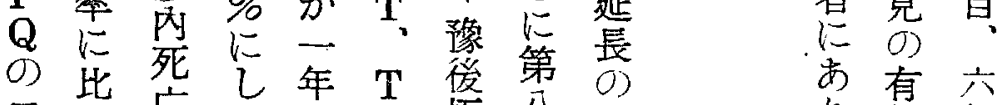

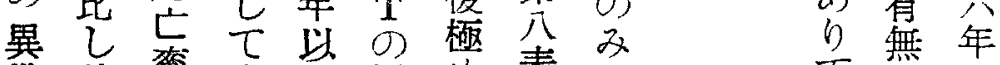
常稍率高㐫變め表—正目 延 3 : 值死华它如五例拘是

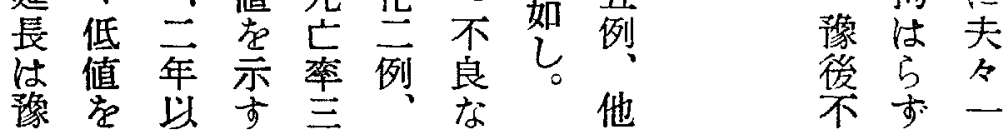


公郎他 裂乙中率

以占のの伴薄等

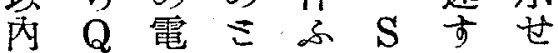

四 T 思宣 $\mathrm{T}$ 万

○異圖惟の

0 常塂 䒓例波㚾度

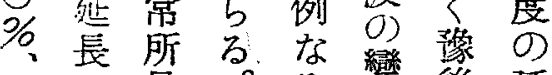

二。見

年 み

の有

全例 無

五に

三人

三楺

क्ष

- - 表

毫年記

正要

常瓜 る

電死 第

宮窈

群生。

例 $\overrightarrow{0}$ 至

此 $\bigcirc_{0}^{\circ}$

万 篎 筏 趠

㾜極 長

以伴市極

宁宗不極

之总良七

五な高

黎例气 率

見る

良 $\mathrm{R}$ 做

な $\mathrm{S}$ 岂

る の 年

異著入以

常盟血

所な壓に

見る 死

の結

併及以湾

热分志

(8: 死六化 $\bar{O}$ 脚 例五

$\mathrm{Q}$ 因杂五塞三五

$\mathrm{R}$ 公房に党

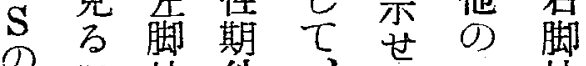

著に杜外、り - 想

音

四塞收左。例 塞

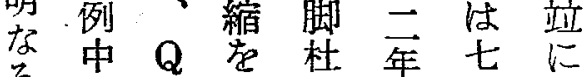

列

新

節

芬

例 $\mathrm{T}$ 示

異せ $Q$ 年誘年中

心常り $\underset{T}{Q}$ 死芓導员年

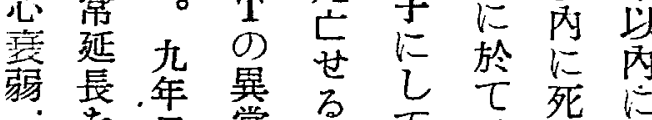

他宗眸延

のせ死長例血 $\mathrm{T}$ せ

二例。例

列

腦

は琇灻琞先年

志誘年五等公目

年䍗七電年に

女於子五湶㚣例

な

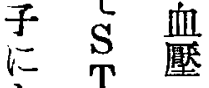

乙 \begin{tabular}{lll}
$\mathrm{T}$ & 亲 \\
\hline
\end{tabular}

期 血九

低壓年

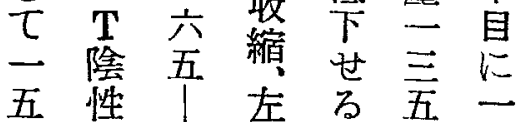

\begin{tabular}{|c|c|c|c|c|}
\hline 㝚 長 佂 & $\overline{\mathrm{I}}$ & $\bar{I}$ & m: & 計 \\
\hline 例 & 31 & 8 & 13 & 52 \\
\hline 1 年以内死亡數 & $7(22.6 \%)$ & $6(75.0 \%)$ & $4(30.8 \%)$ & $17(32.7 \%)$ \\
\hline 2 年 & $14(45.1 \%)$ & $7(87.5 \%)$ & $7(53.8 \%)$ & $28(53.8 \%)$ \\
\hline 年 & $16(51.6 \%)$ & 7 & $9(69.2 \%)$ & $32(61.4 \%)$ \\
\hline 4 年 & $18(58.1 \%)$ & 7 & $9(69.2 \%)$ & $34(65.3 \%)$ \\
\hline 5 年 & $20(64.5 \%)$ & $8(100 \%)$ & $9(69.2 \%)$ & $37(71.1 \%)$ \\
\hline 6 年 & 21 & 8 & 9 & 38 \\
\hline 7年 & 22 & 8 & 9 & $39^{\circ}$ \\
\hline 8 年 & 24 & 8 & 10 & 42 \\
\hline 9 年 & 26 & 8 & 13 & 47 \\
\hline E存例夏 & $516.1 \%$ & 0 & 0 & $5(9.6 \%)$ \\
\hline
\end{tabular}

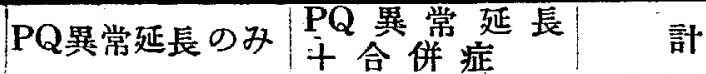

\begin{tabular}{|l|l|l|}
15 & 14 & 29 \\
\hline $0 \%(35.7 \%)$ & $5(17.2 \%)$
\end{tabular}

\begin{tabular}{|c|c|c|}
\hline$(20.0 \%)$ & $\frac{7}{12}(50.0 \%)$ & $\frac{8(27.6 \%)}{15(51.7 \%)}$
\end{tabular}

$\begin{array}{lll}20.0 \%) & 12(85.7 \%) & 15(51.7 \%)\end{array}$

詨

梦

馬

ii

耆

拲

氣

動

研

若宗 例

为,

急次因

性、岕觉

腸腦

炎溢以死せ例五結

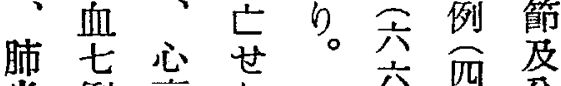

炎 例

の 嫋

順三

な位、例

な。四。例

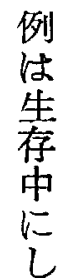

高八る死

$\%$ 例 L

二利造

年 b市

T

屉は高

六一垒

二 年 崖

$\%$ 多

EL

U 弯

合 三 方

并

症八電

な \%心六

き、䦓

例 二 霟

年常

比边 所

L 內 見

死五觉

亡 方空 


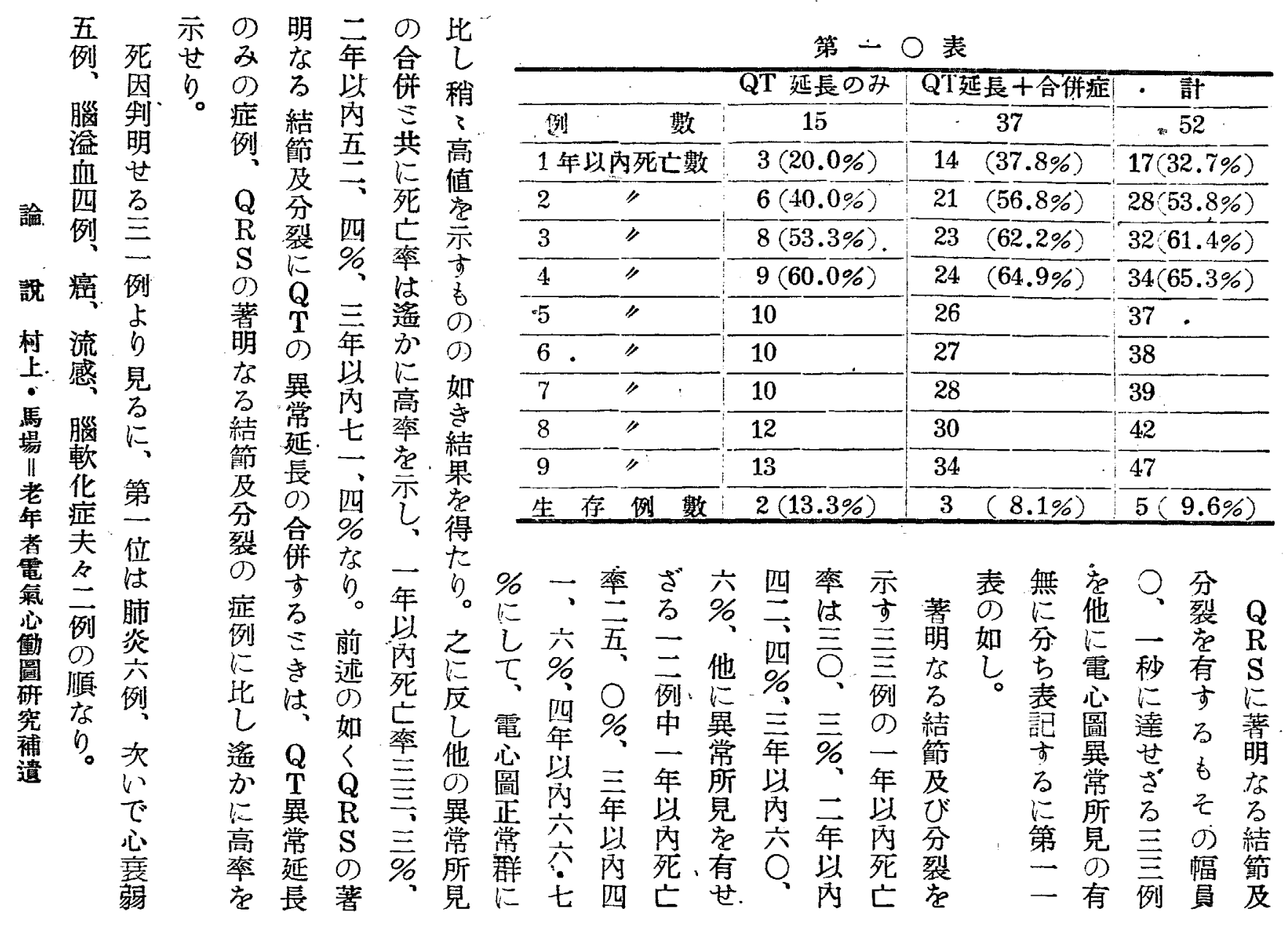

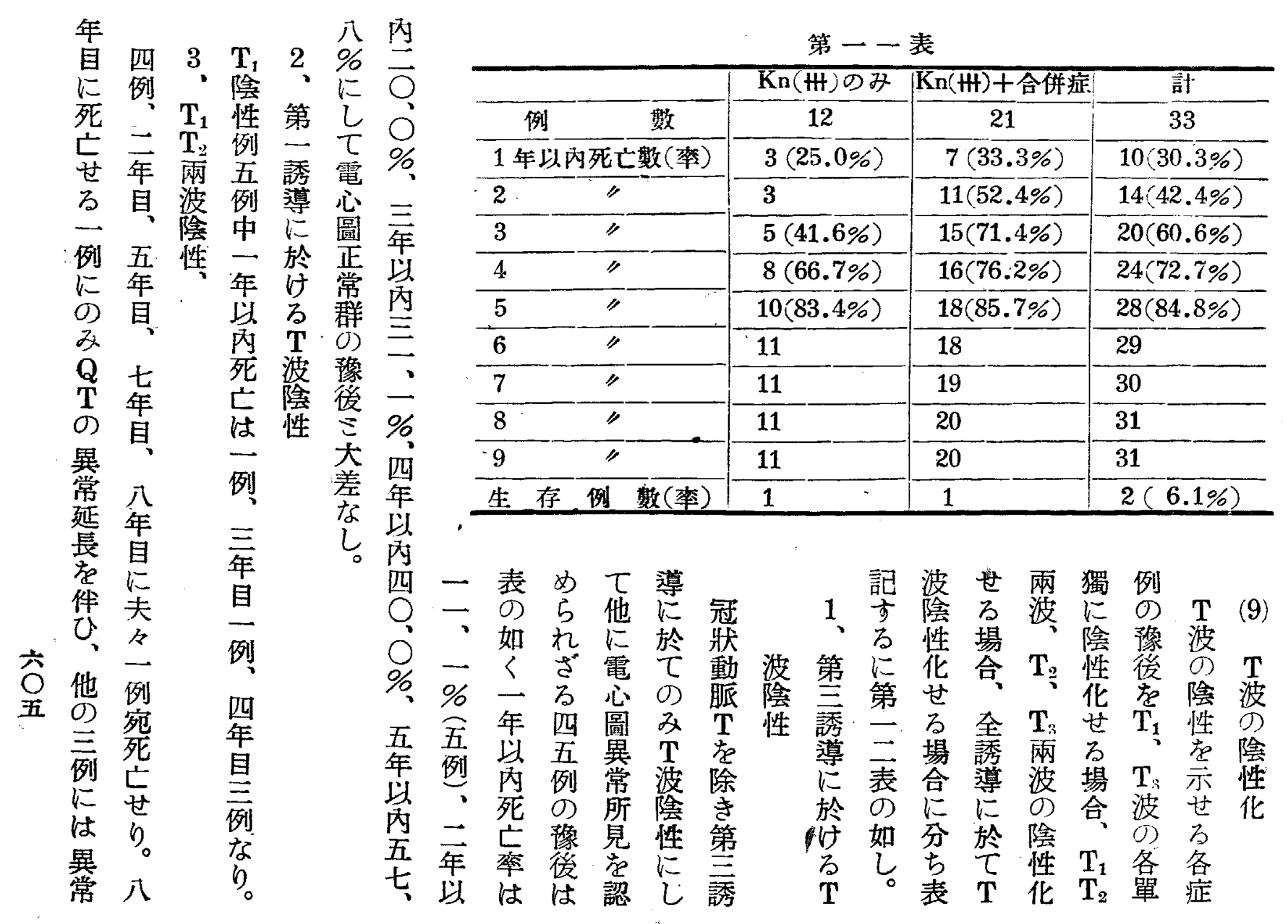




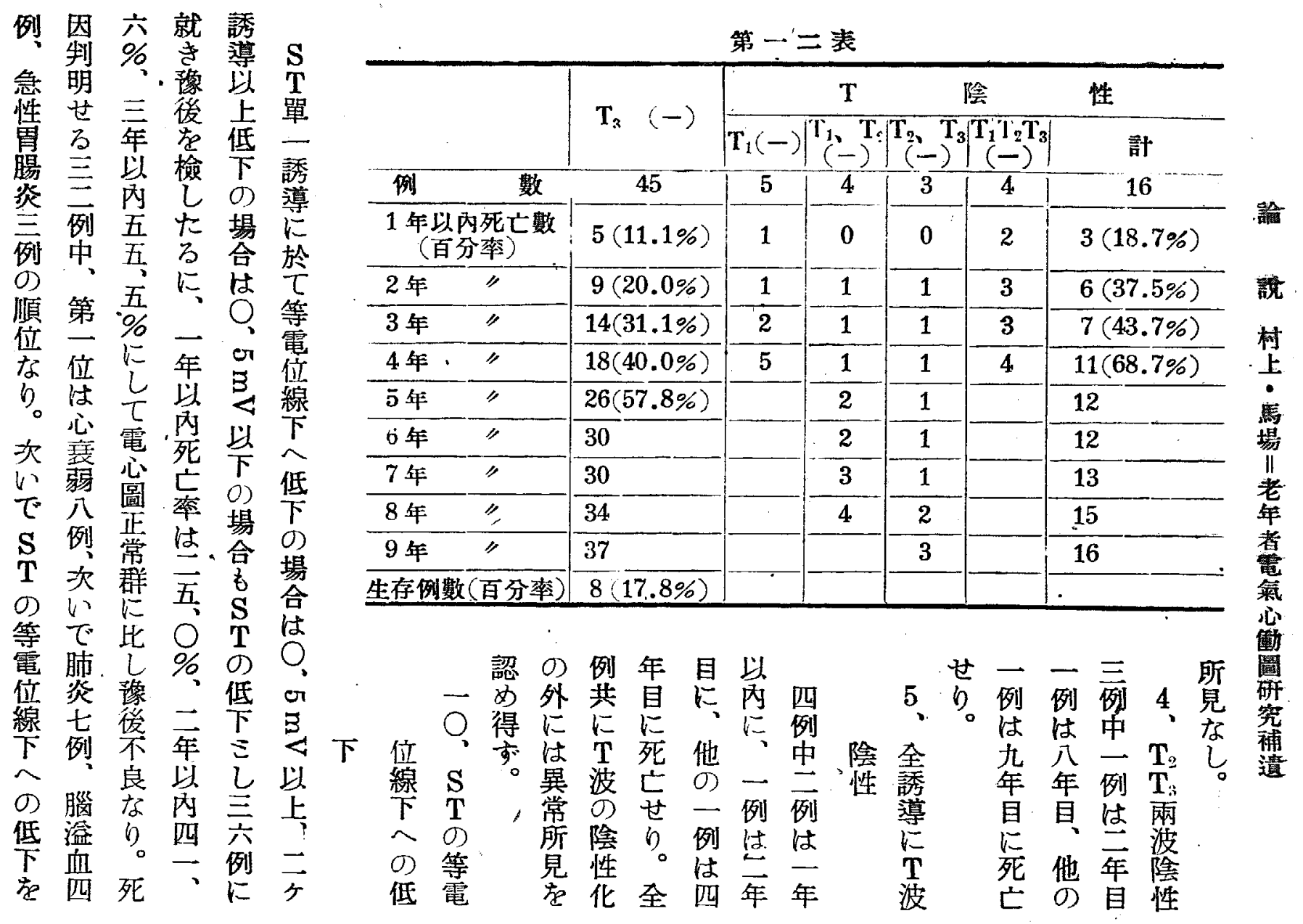

第一 三表

\begin{tabular}{|c|c|c|c|c|c|c|c|c|}
\hline & & $\mathrm{ST}_{1}(\mathrm{tt})$ & $\mathrm{ST}_{3}(\mathrm{H})$ & $\mathrm{ST}_{1 \mathrm{u} .2(+)}$ & $\mathrm{ST}_{1^{\mathrm{n} .2}}(\mathrm{H})$ & $s \mathrm{~T}_{2 \mathrm{u}_{3}}( \pm)$ & $\mathrm{ST}_{2} \mathrm{u}_{3}(\mathrm{H})$ & 訣 \\
\hline 例 & 數 & 4 & 1 & 11 & 13 & 4 & 3 & 36 \\
\hline 1 年以 & 死亡數 & 1 & & $2(18.2 \%)$ & $5(38.5 \%)$ & 1 & 0 & $9(25.0 \%)$ \\
\hline 2 年內以 & $2 "$ & 1 & & $5(45.5 \%)$ & $6(46.2 \%)$ & 2 & 1 & $15(41.6 \%)$ \\
\hline 3 & $"$ & 2 & & $6(54.6 \%)$ & $9(69.2 \%)$ & 2 & 1 & $20(55.5 \%)$ \\
\hline 4 & " & 2 & & 6 & $11(84.6 \%)$ & 2 & 1 & $22(61.1 \%)$ \\
\hline 5 & $"$ & 3 & & $7(63.7 \%)$ & 11 & 2 & 2 & $25(69.4 \%)$ \\
\hline 6 & " & 3 & & 7 & 11 & 2 & 2 & 25 \\
\hline 7 & " & 3 & & 8 & 11 & 2 & 2 & 26 \\
\hline 8 & $"$ & 3 & . & 9 & 11 & 3 & 2 & 28 \\
\hline 9 & " & 4 & & 9 & 13 & 3 & 2 & 31 \\
\hline 生 存 & 數 (萃: & & 1 & 2 & & 1 & 1 & 5 \\
\hline
\end{tabular}

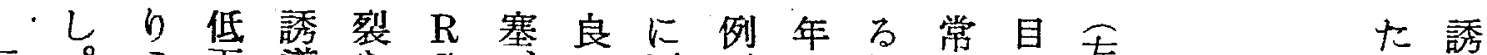

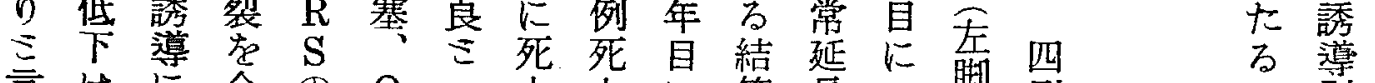

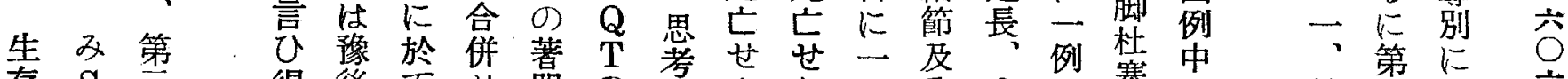

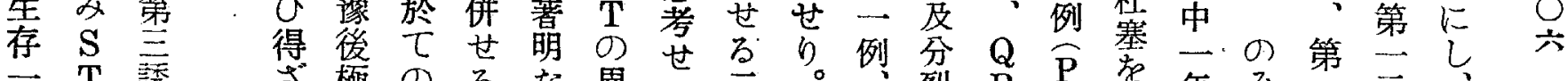

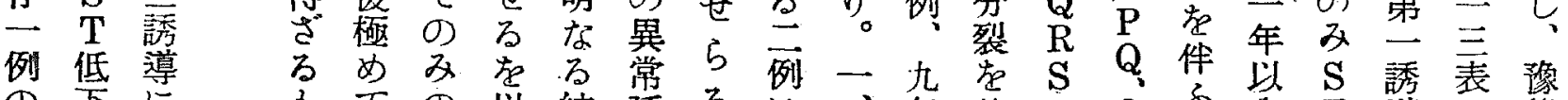

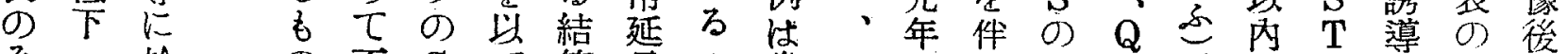

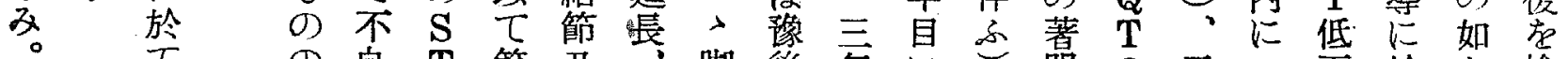

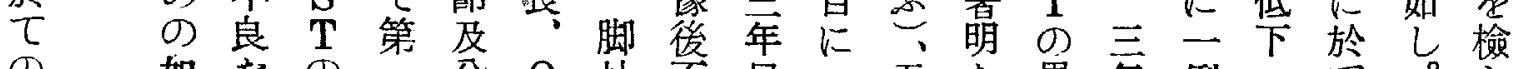
の 如なの分 $\mathrm{Q}$ 杜不目一五な異年例宁。筧 


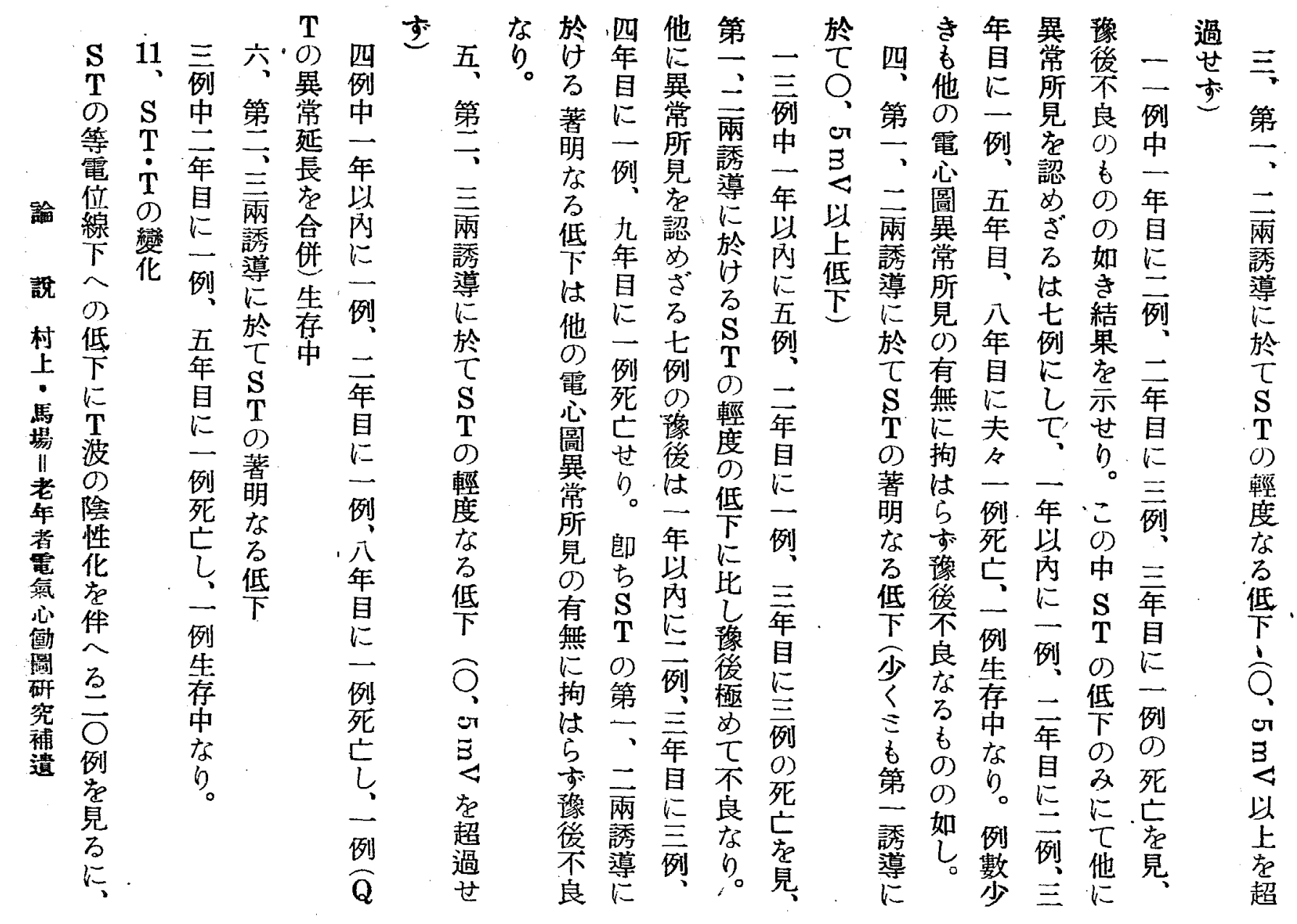

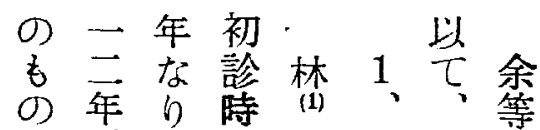

上、卡は血以は

门 血 $＼mathrm{~ 死 本 壓 卡 血 ~}$

潒檿: 死態 各壂

荄進本至血㣪自電

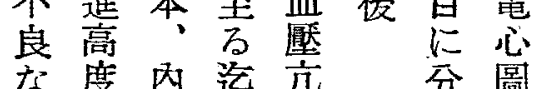

な 度间迄尣分圖

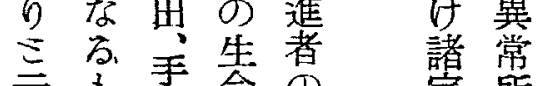

云当塚命 $\sigma$ 萣所

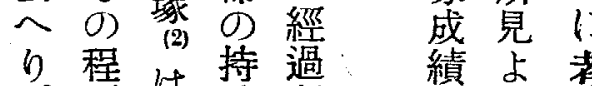

り桯は持過、續 よ

森孪定最せ明 比見

森孪發最せ 短し 較た

は高病短厹蔡老

血く、年方五年

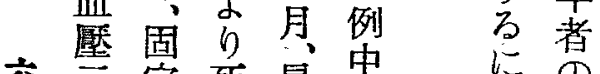

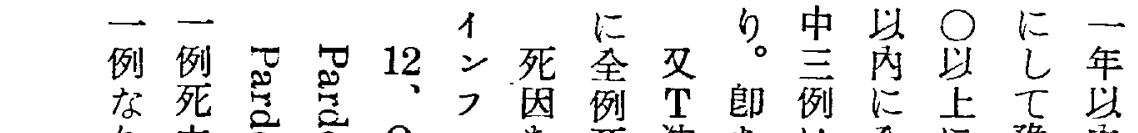

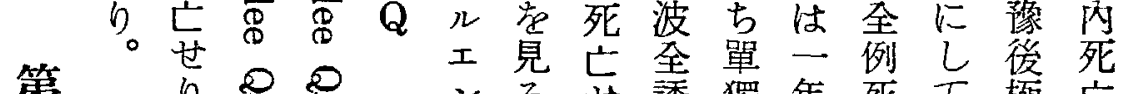
第 り

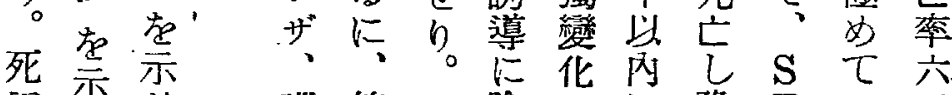
因婪腦第陰可豫 $\mathrm{T}$ 不五

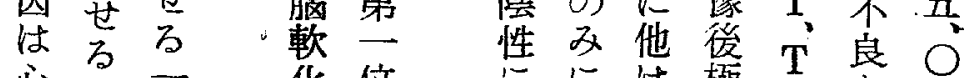

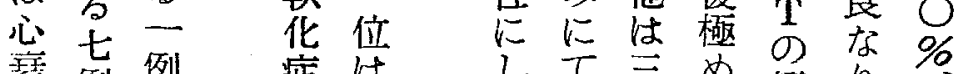

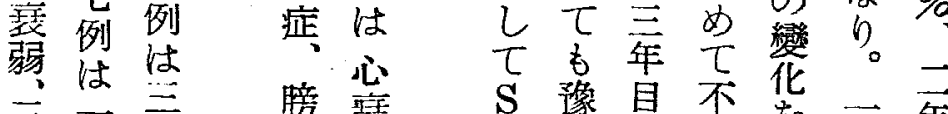

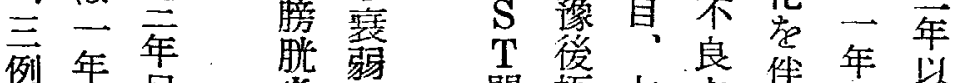

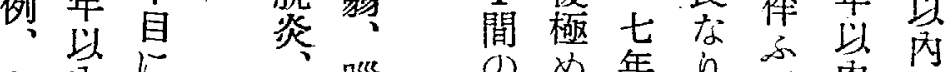

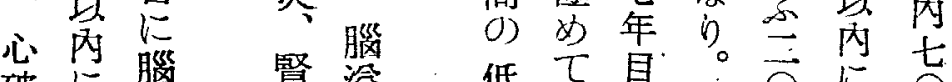

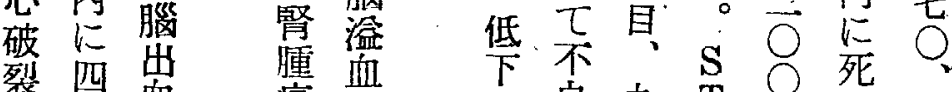

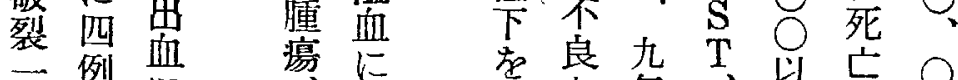

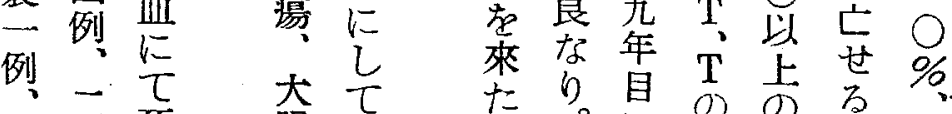
六二定死 最死 头手 $\sigma$ ケ 元 如宫

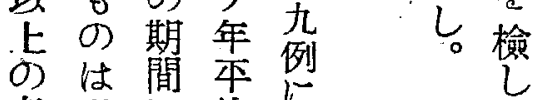
者動は均に元代

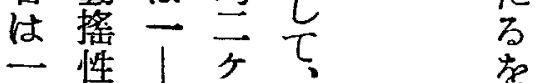

肺 年 死 炎自亡 例 $\frac{1}{\text { 例 }}$

脑

軟 五

化年

症目

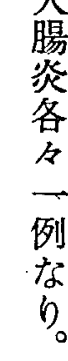

謷备

せ。に継高二

る夫化血严

四々 $O$ 壓例以

例 み

は例学一九七

年死宗例例五

年 死咅 
\%順大九位け壓一腦血㷧。於如の1認示圖壓群る゙

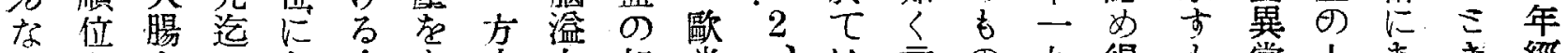

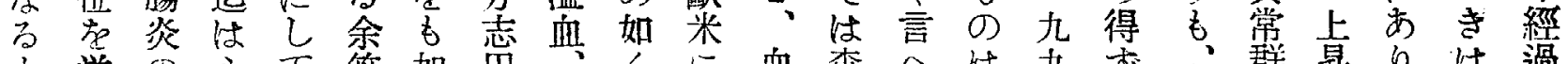

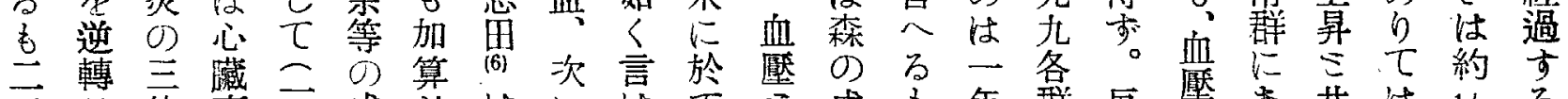

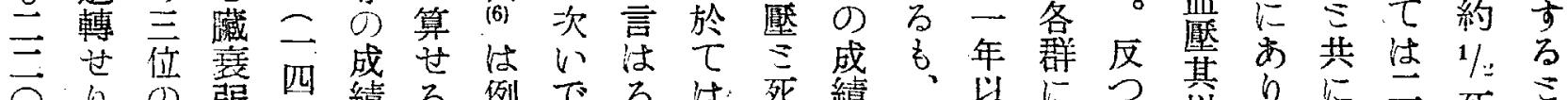

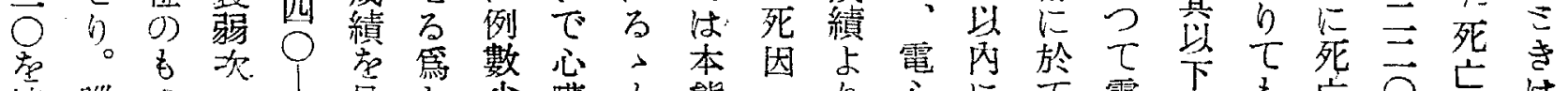

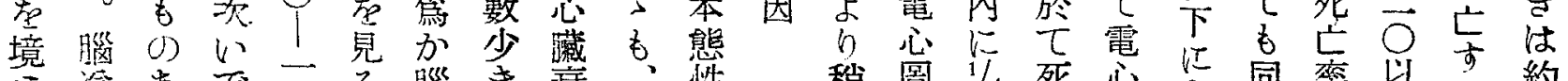

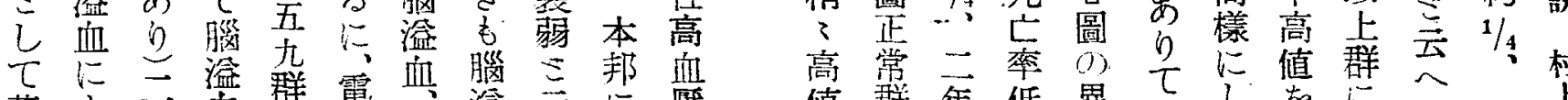

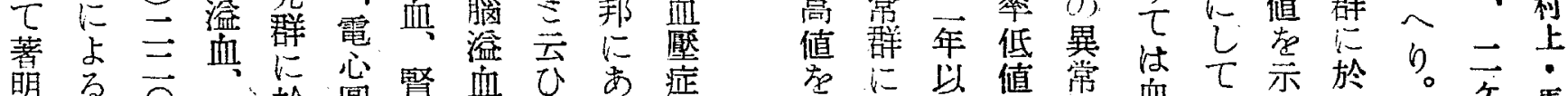

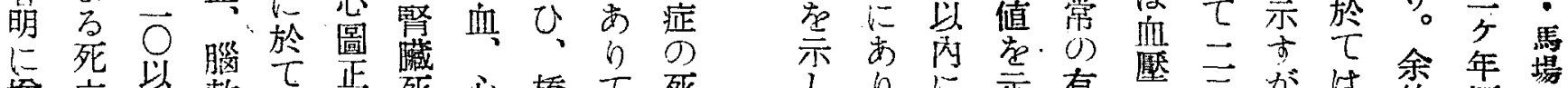

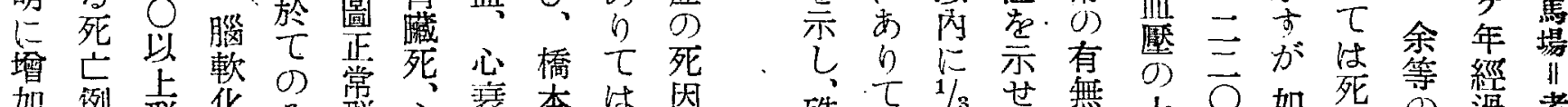

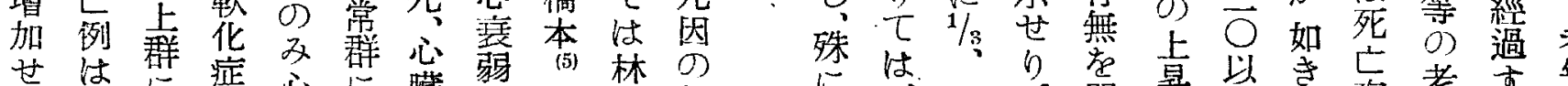

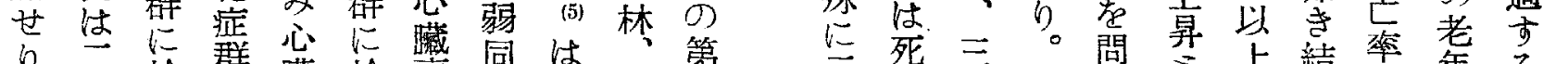

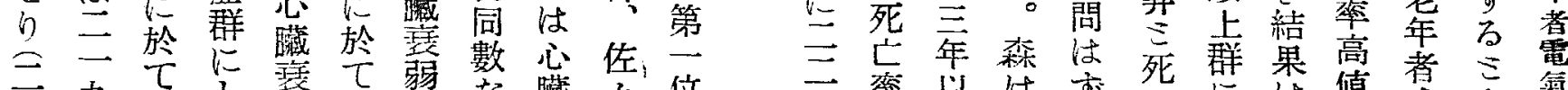

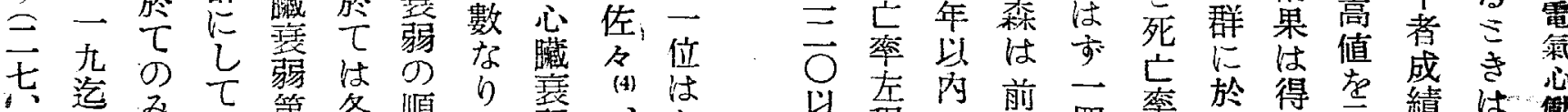
八 は腦、第各順

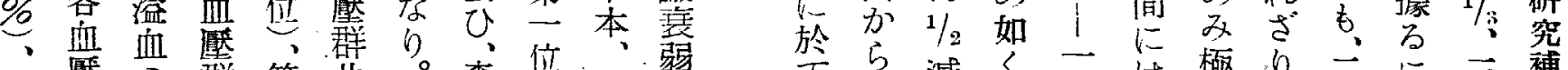

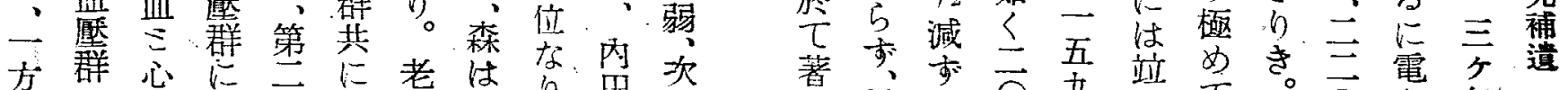

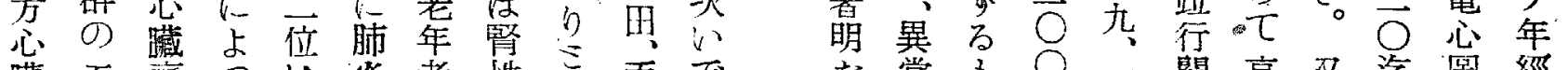

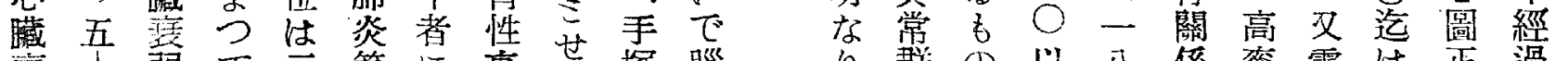

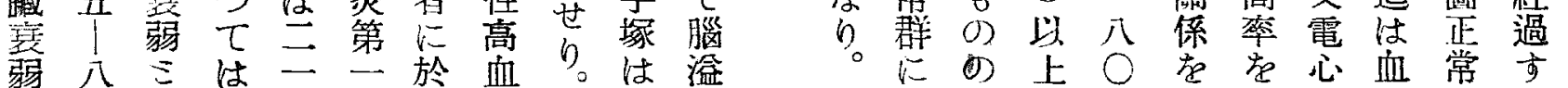

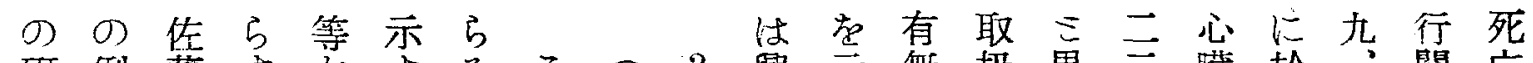

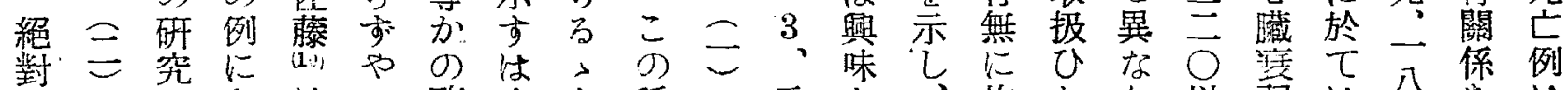

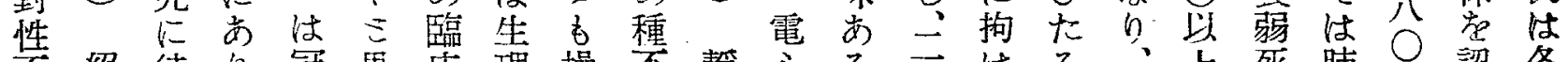

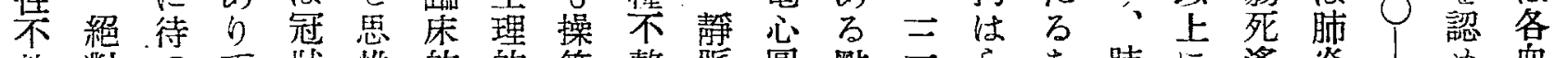

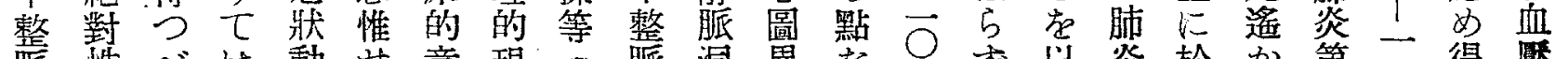

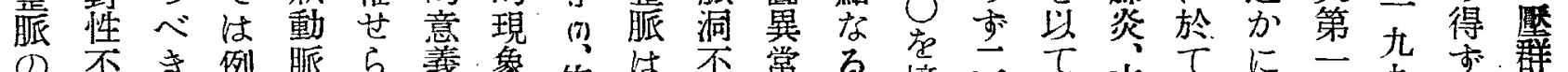

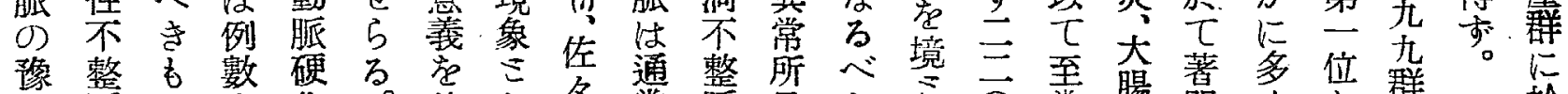

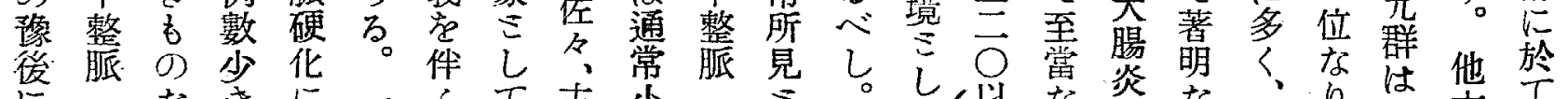

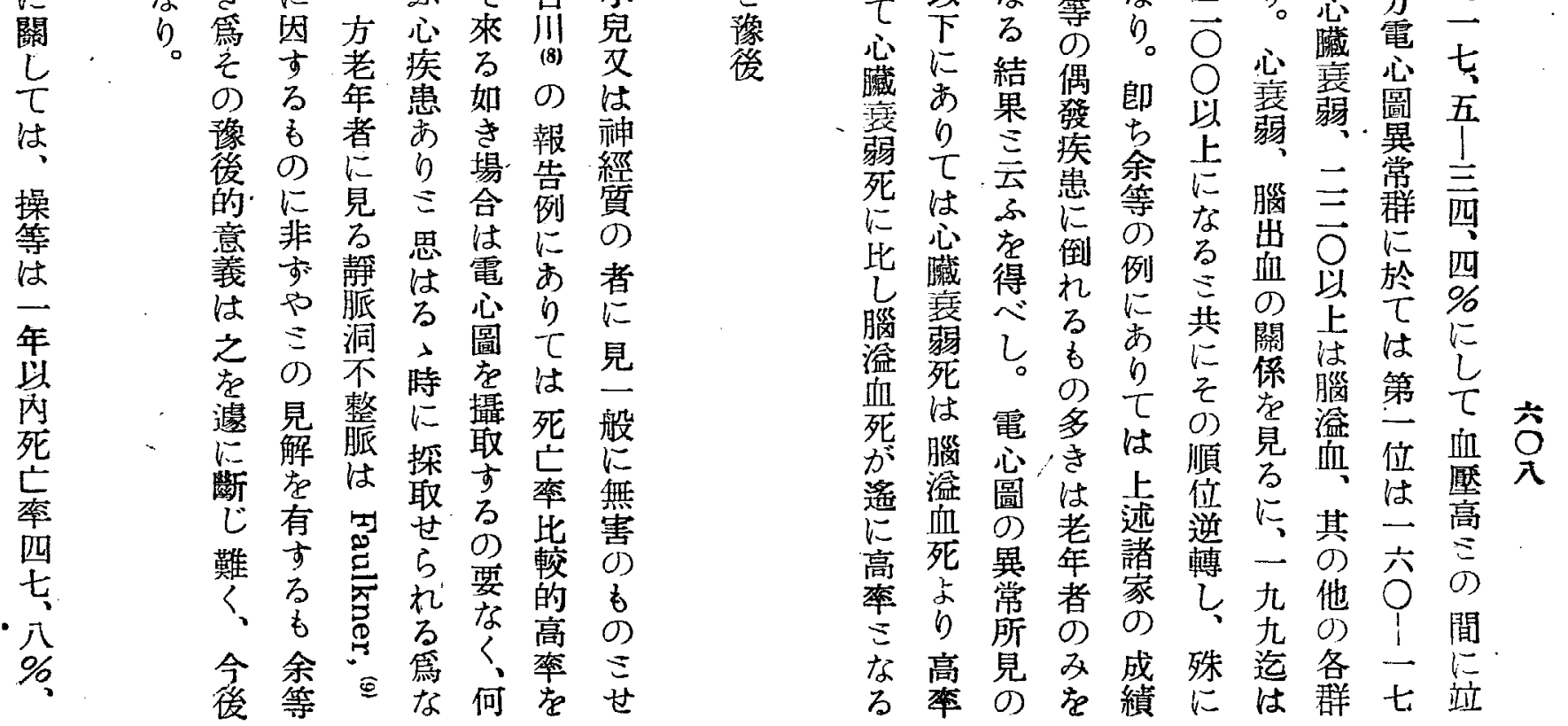




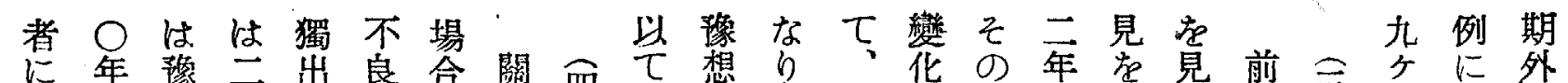

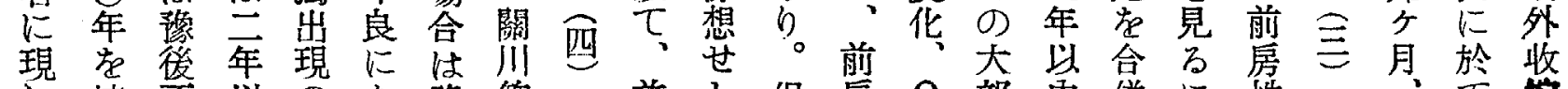

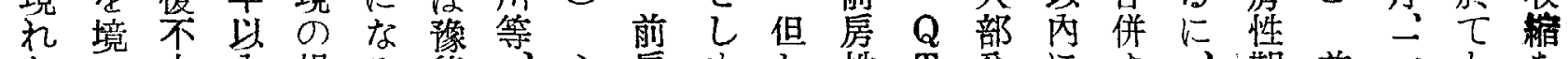

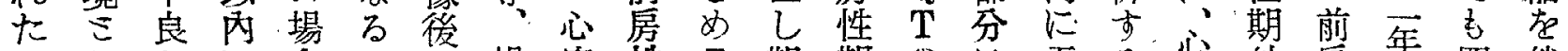

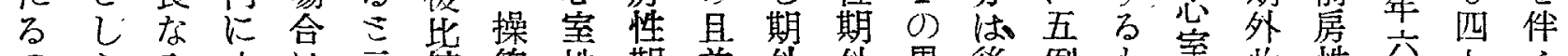

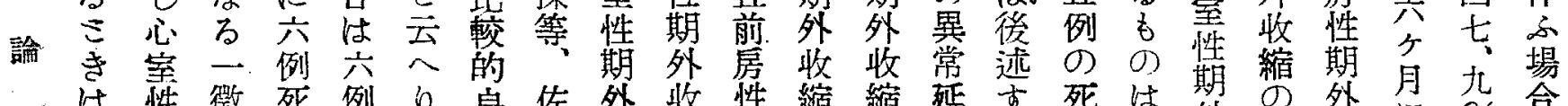

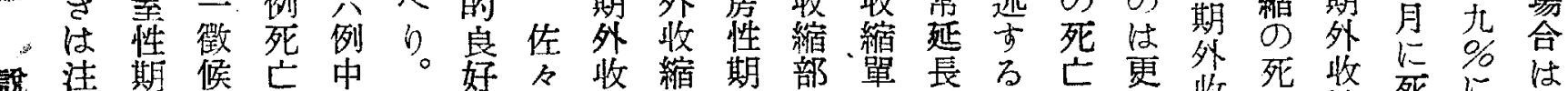

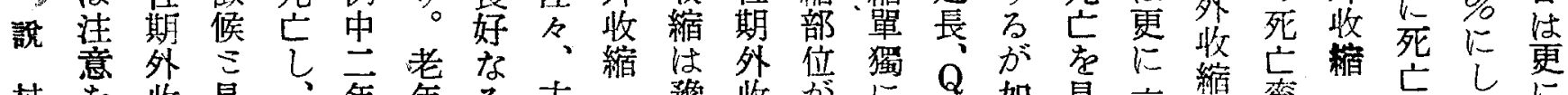

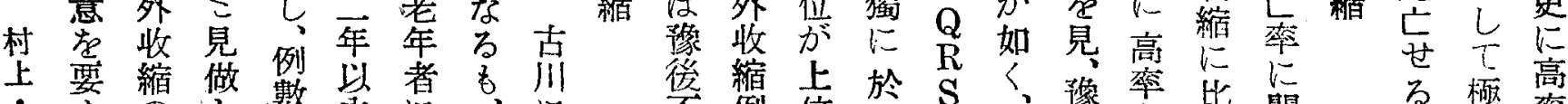

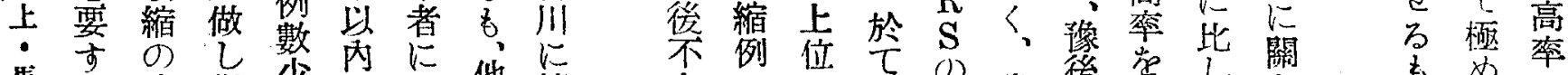

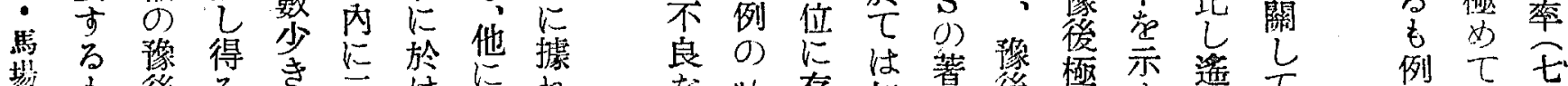

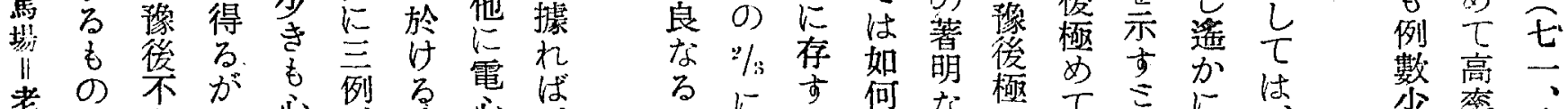

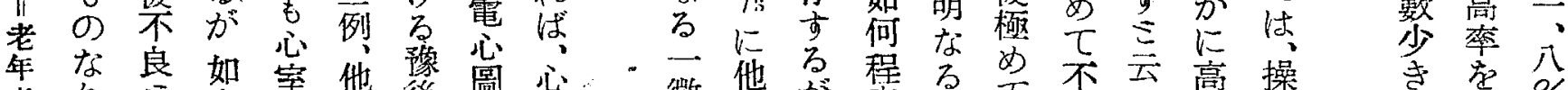

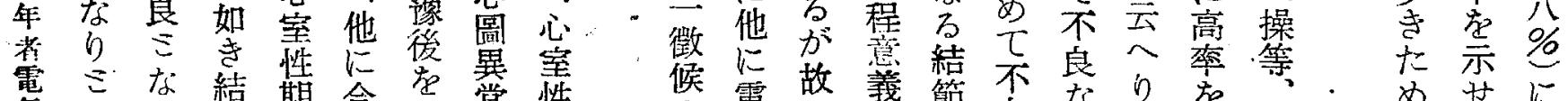

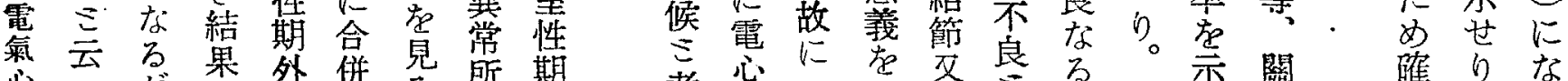

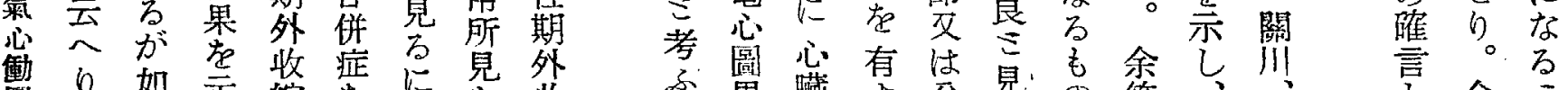

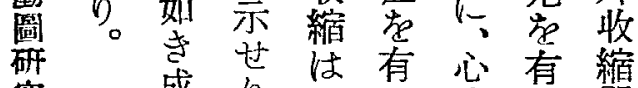
究盛り。老古室古緧

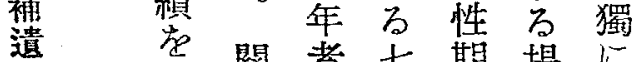
㳫關者七期場点

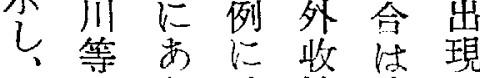
老名 り 於縮豫 す

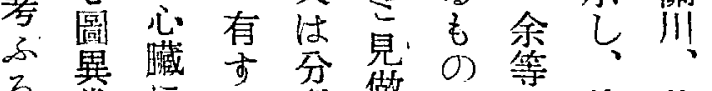

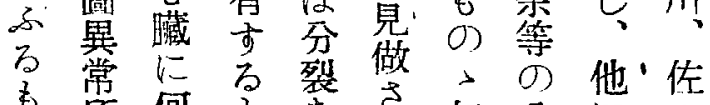

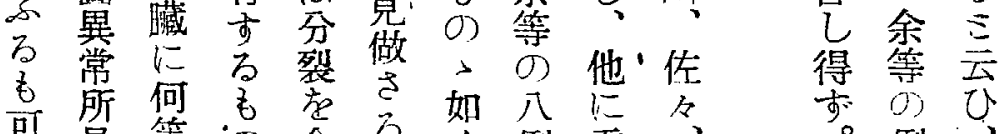

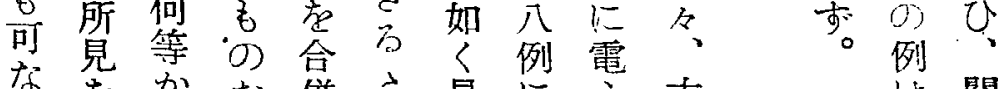

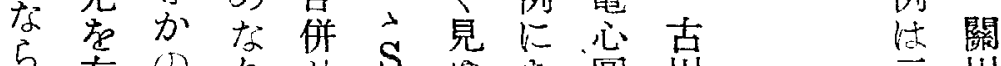

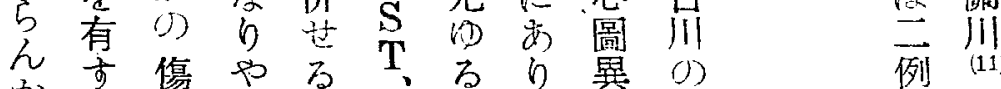

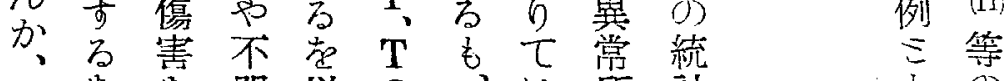

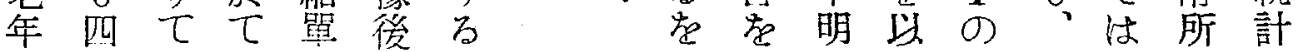

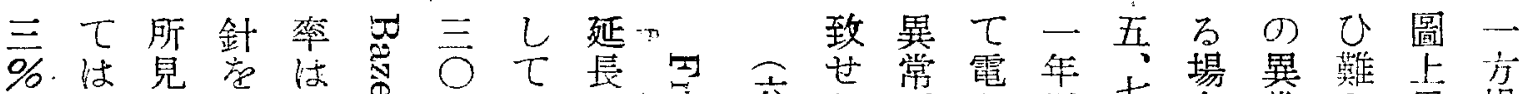

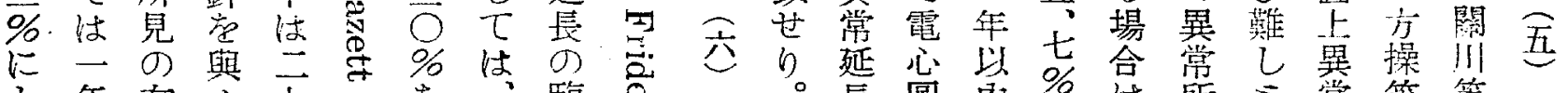

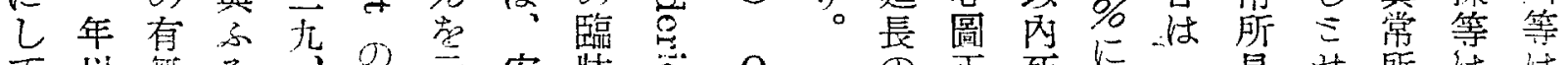

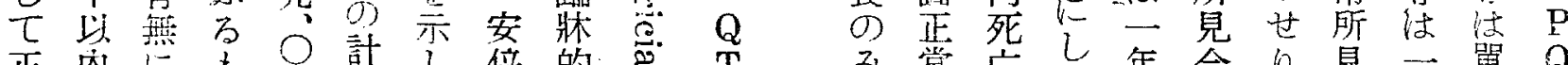

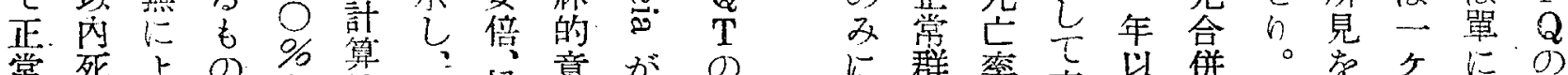

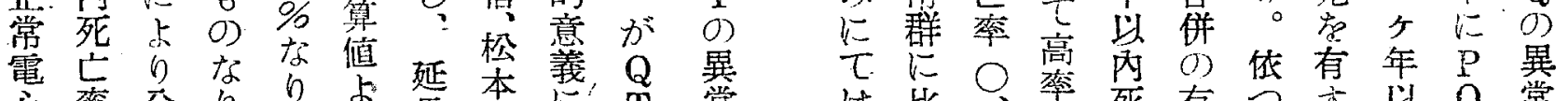

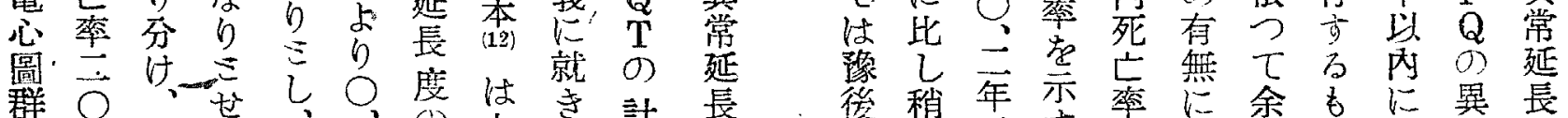

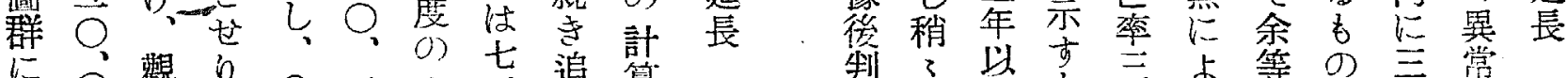
に 0 憼

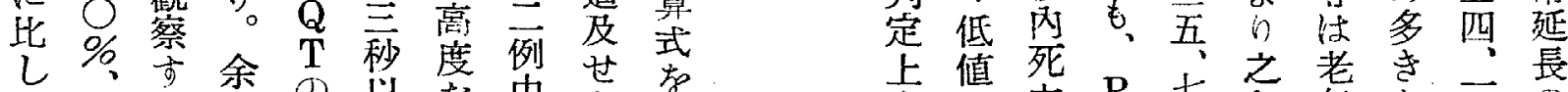

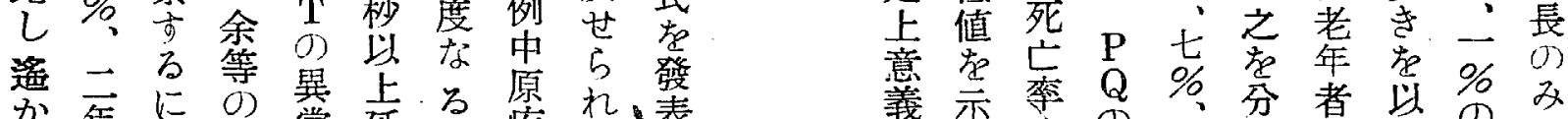

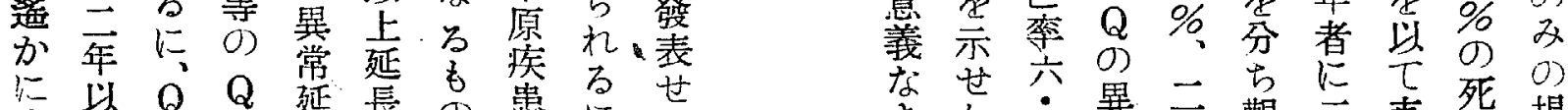

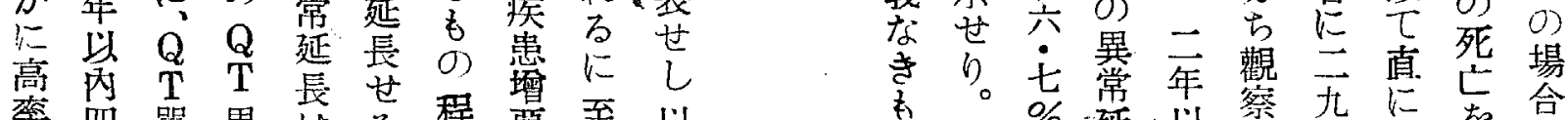

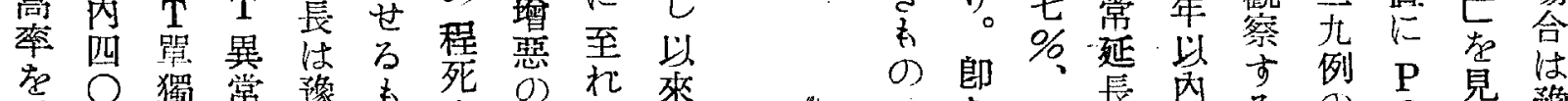

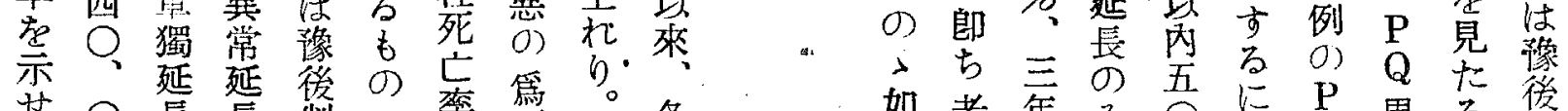

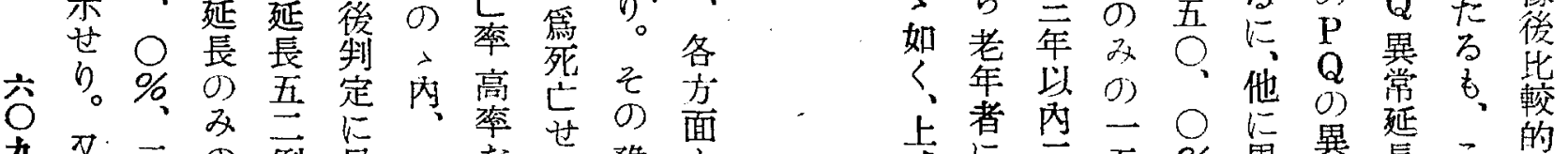

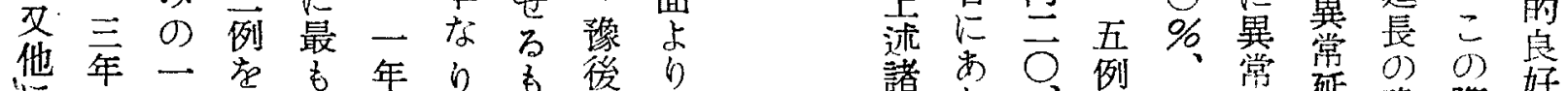

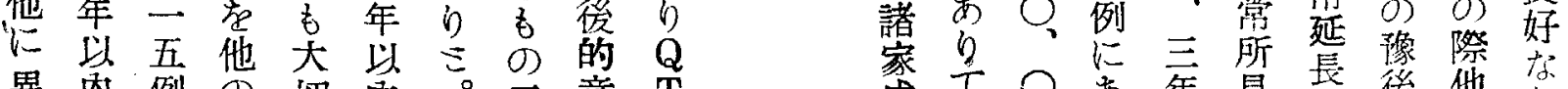

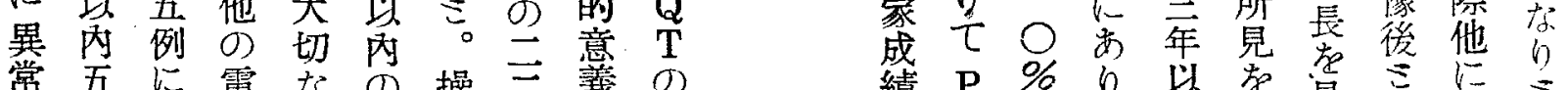

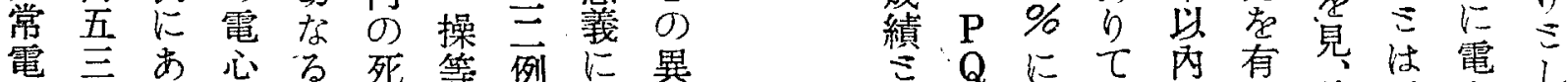

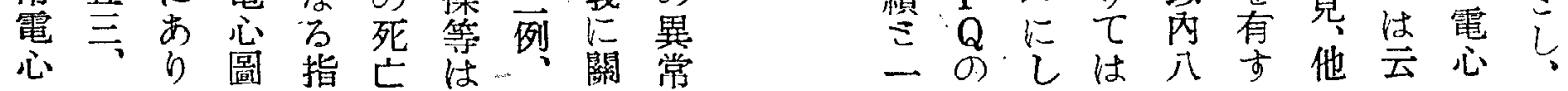


は時に

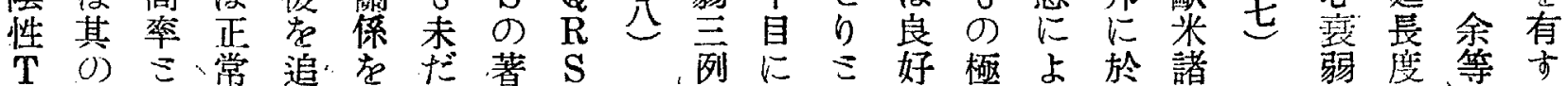

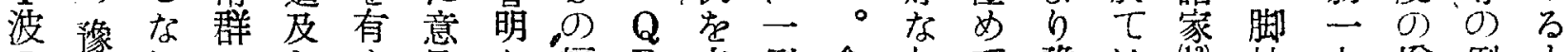

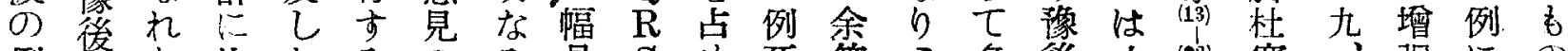

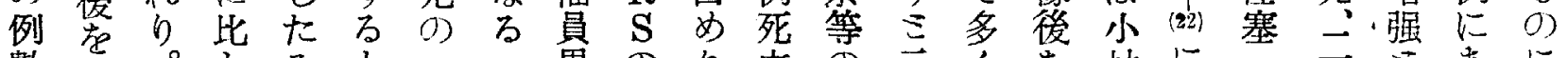
數虚

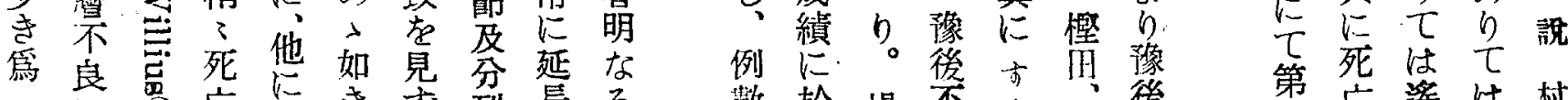

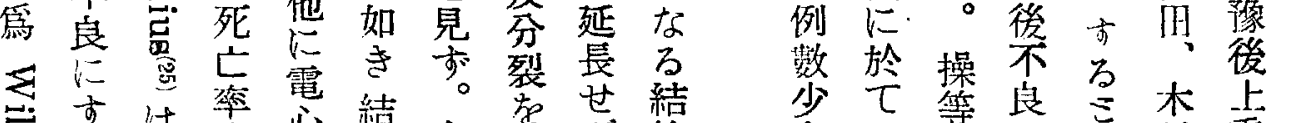

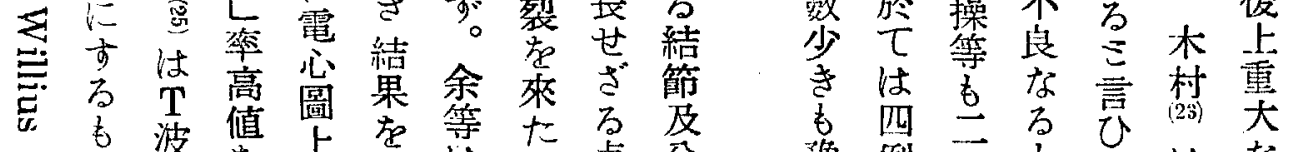

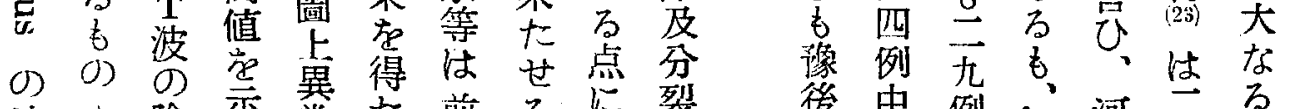

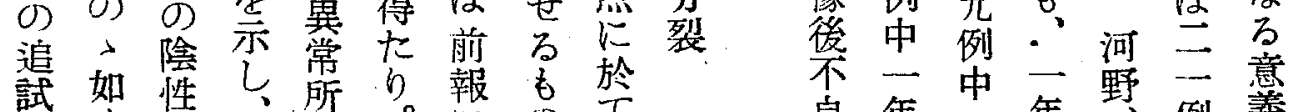

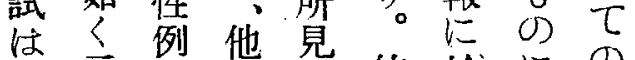
行云烈他見依於にの ひ人 $\mathrm{Q}$ 異有つ它於み 得 る $\mathrm{R}$ 裳せ七冠艺脚 ざ し等分のる视脈々に も向裂 合二之硬論合 例結 併三等化議致 是に節气例㤩士世せ 等西共共に永何らざ 所り伴に市例等机る 見七心更り口少た $\mathrm{Q}$

良年二年野例意

な 以年以松の学

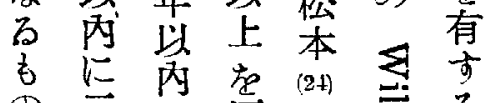

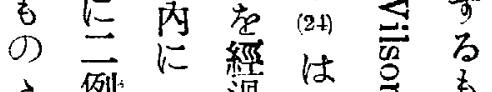

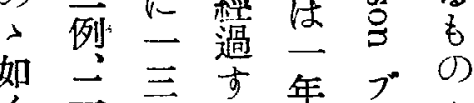

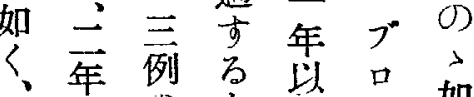

死自年烈

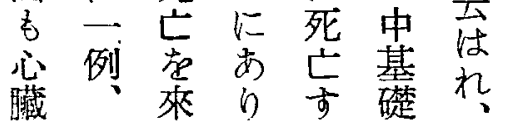

第死は遙は村

位慗に安上

萑 0 高倍要

占点夿松場

万劣示は老

は來せ單年

與たり。獨省

あり 味爸長雨

あ。安長忍

點死倍比圆

な因松し确

り制本大究

明り差補

万人

四る

七がす

例如 万

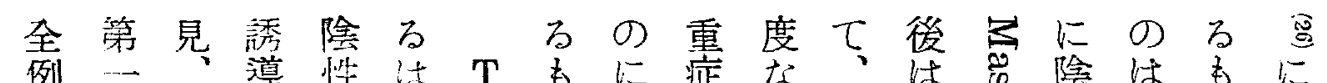

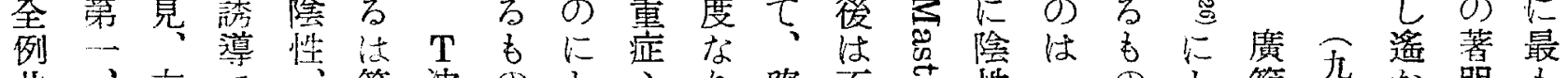

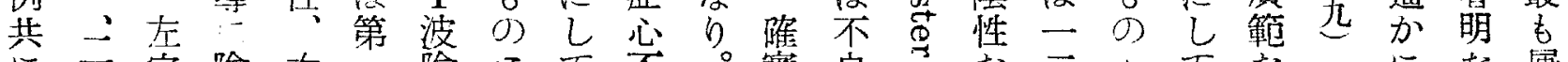

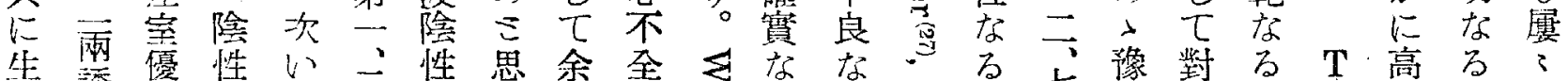

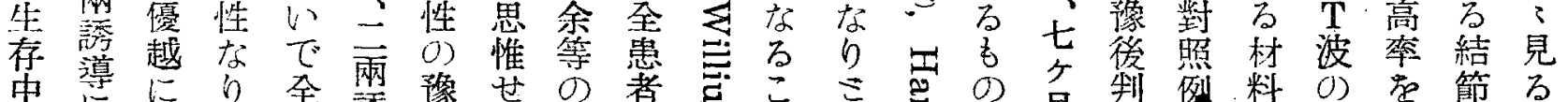

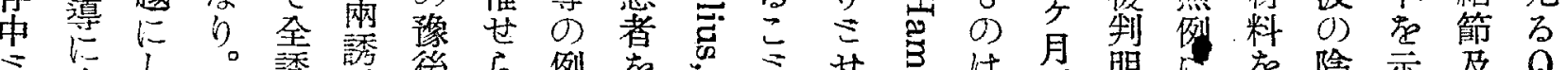

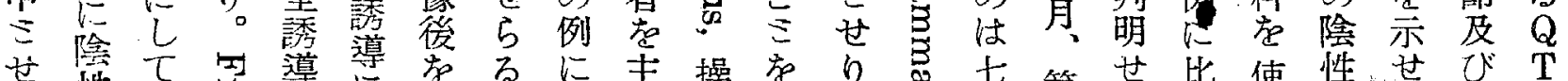

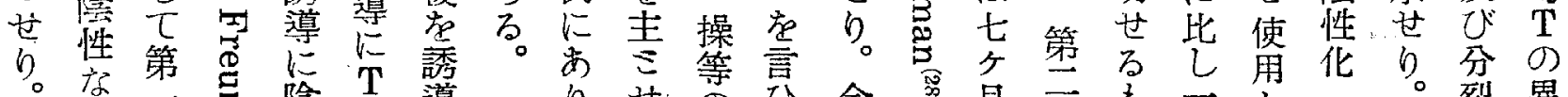

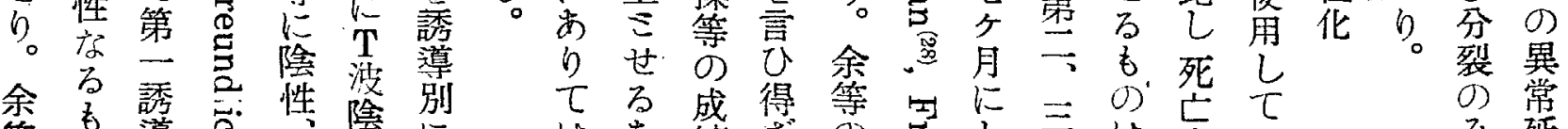

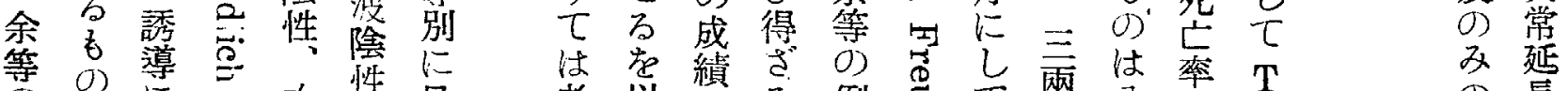

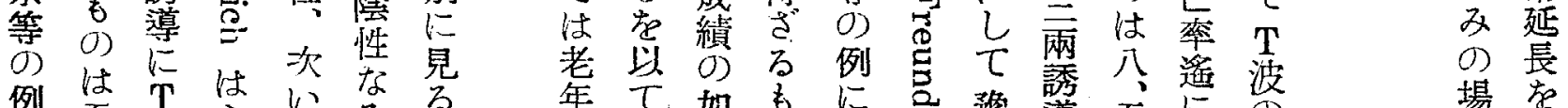

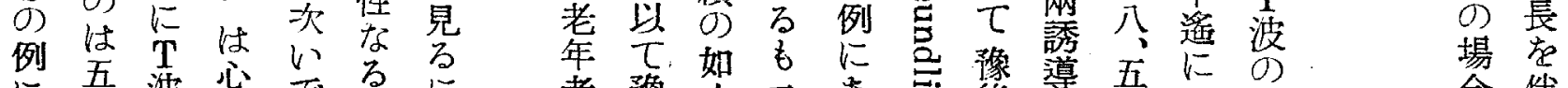

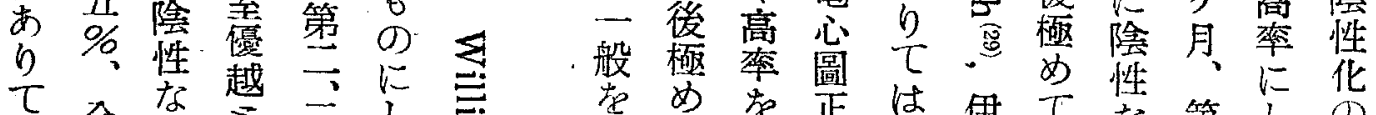

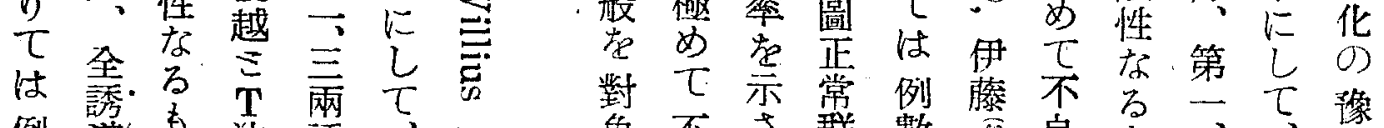

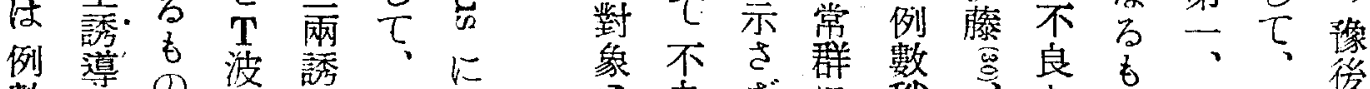

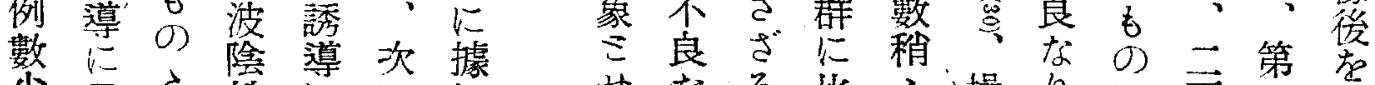

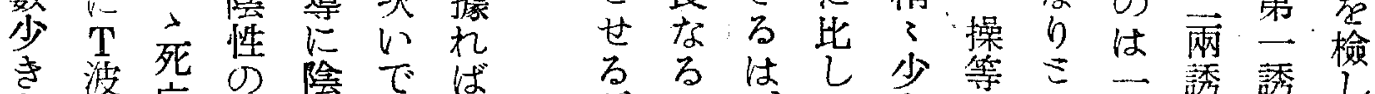

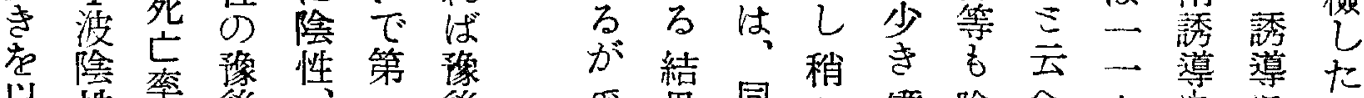

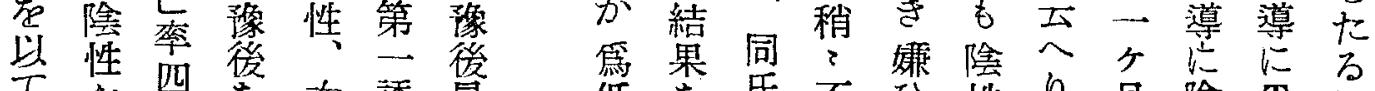

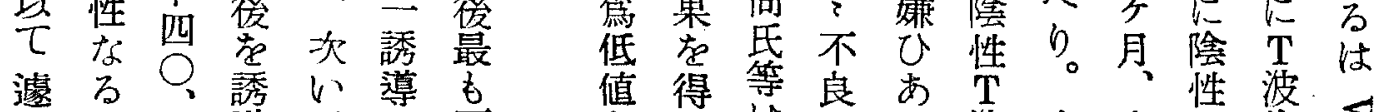

には五導でに不虎た蛙な波次全な会 $\mathrm{Q}$

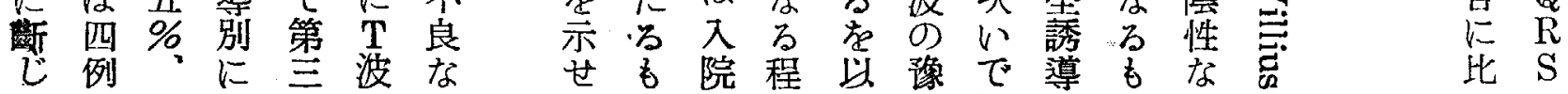


績 中據 $\mathrm{S}$ 二盛陸

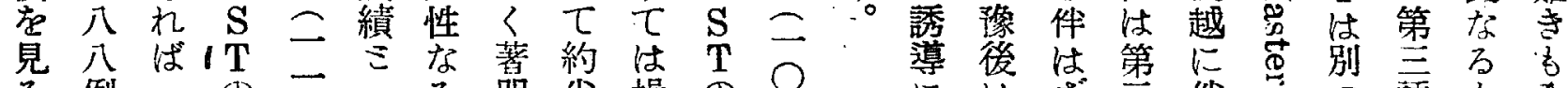

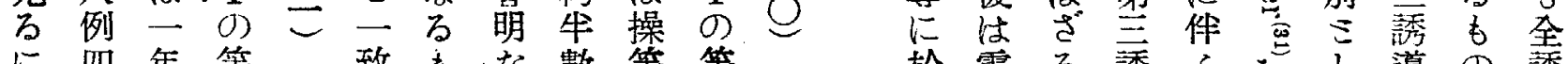

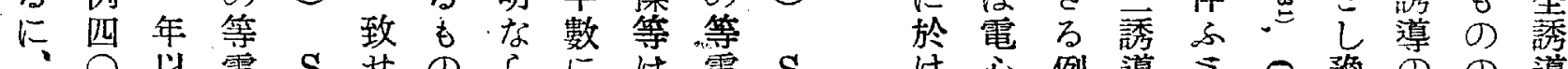
二

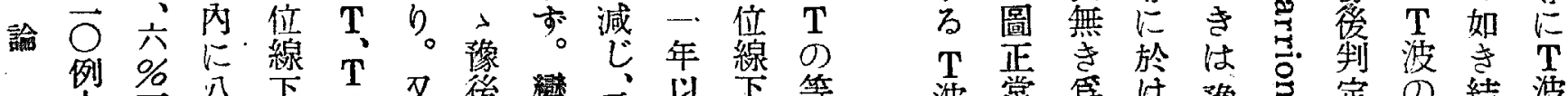

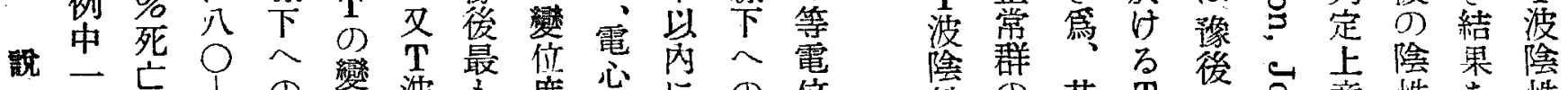

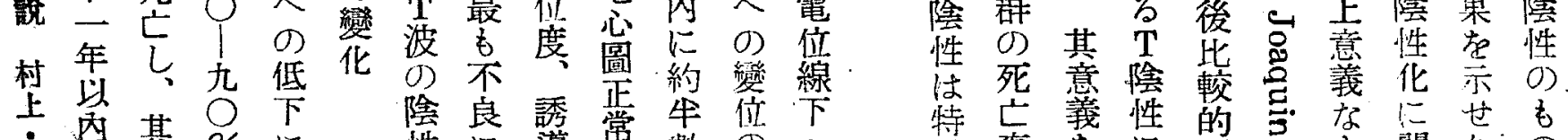

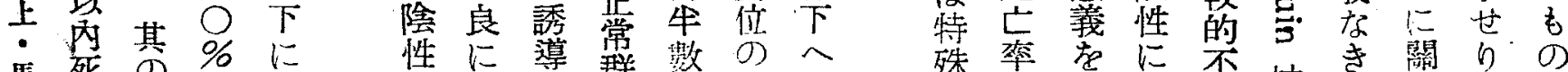

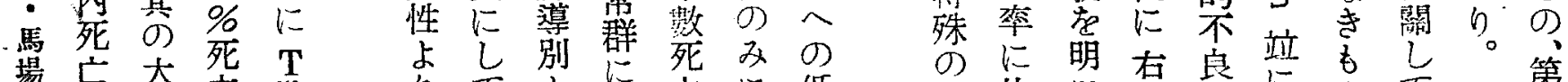

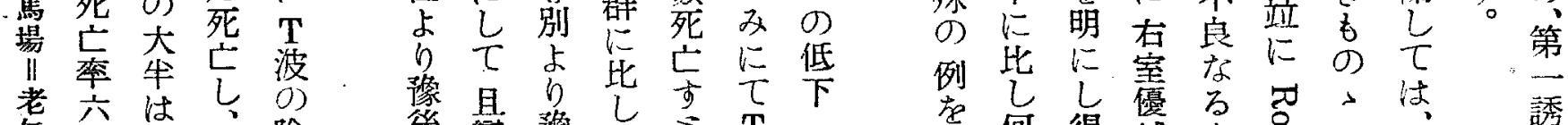

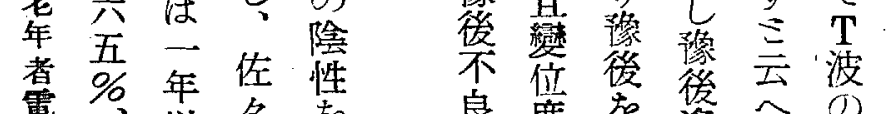

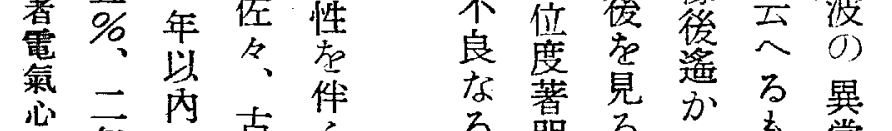

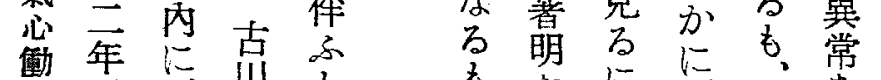

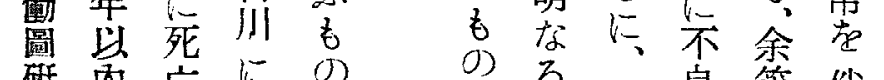
研究亡年據小等件

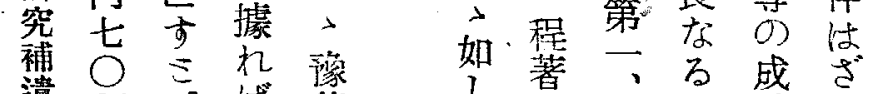

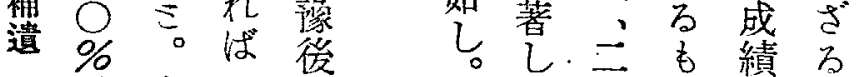
三余二操操霖操等症

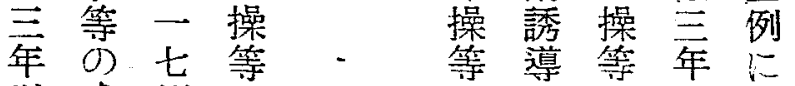

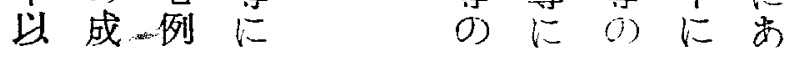

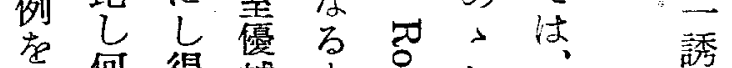
除等 得越主总如心 心 萛

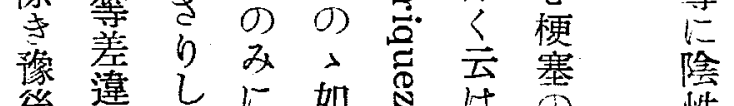

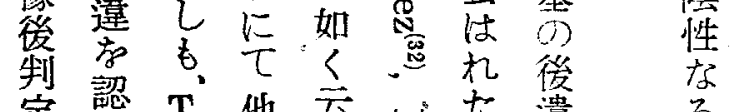
定㴔 $\mathrm{T}_{:}$他云可た遺方 上得三電

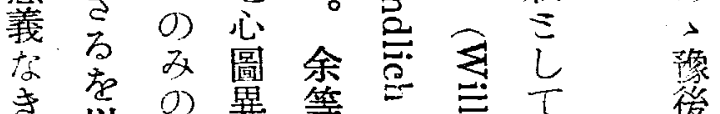

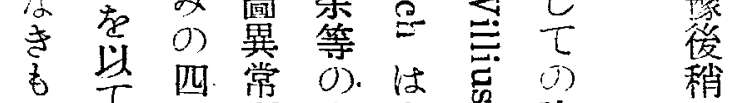

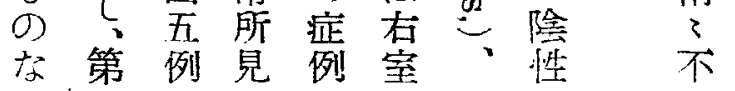

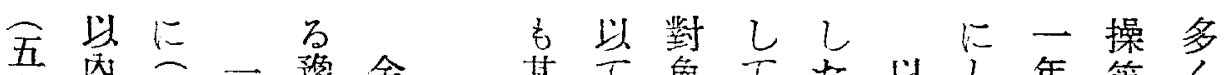

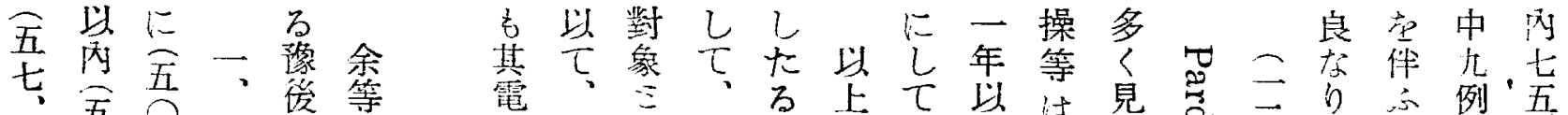

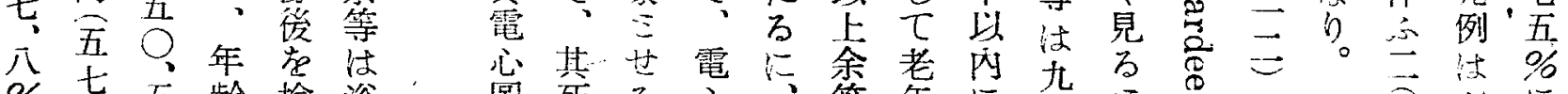

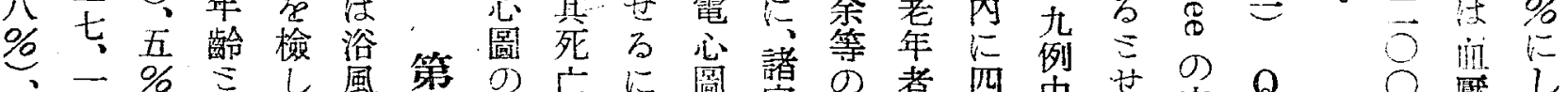

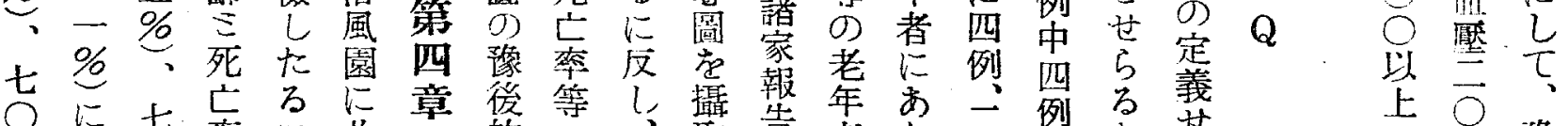

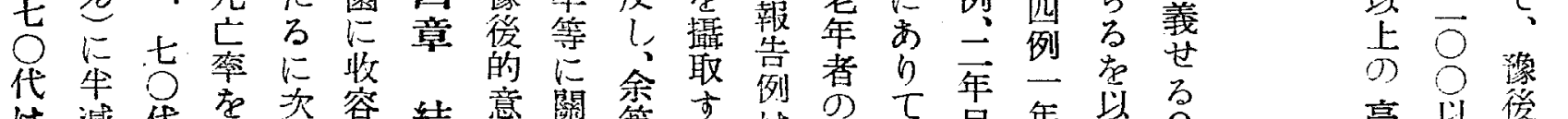

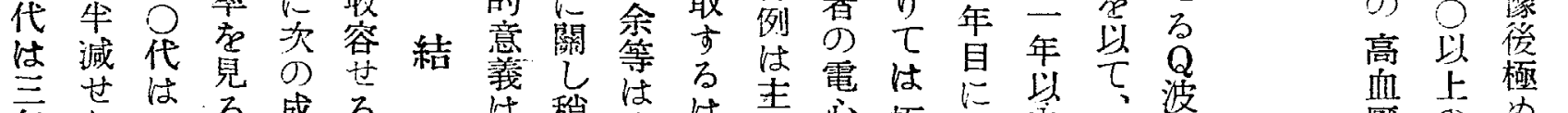

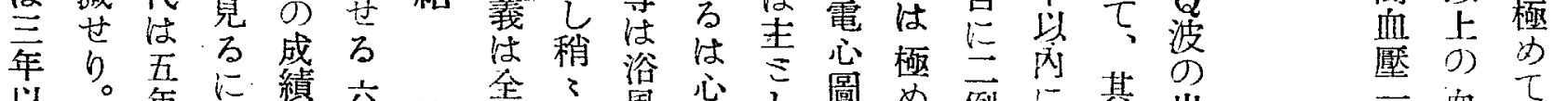

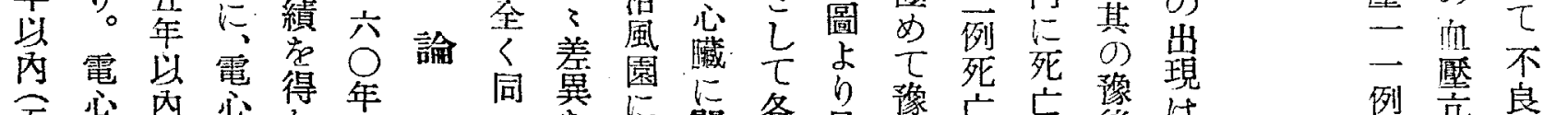

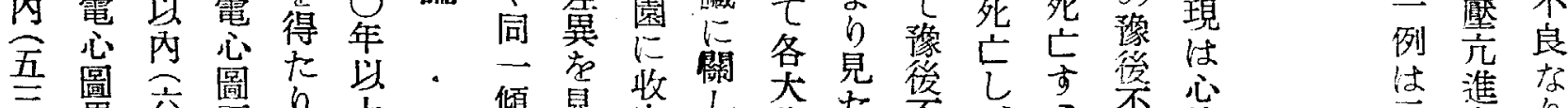

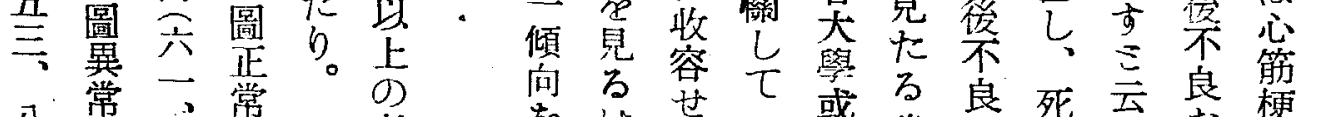

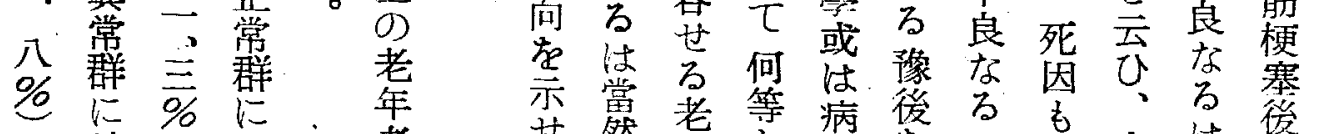

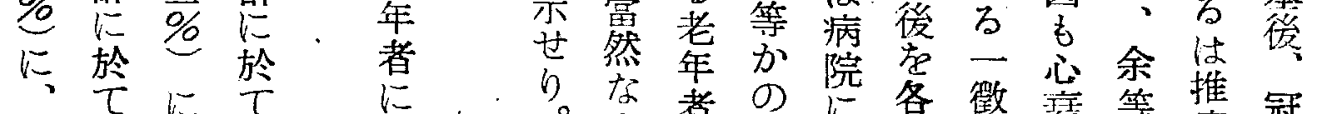

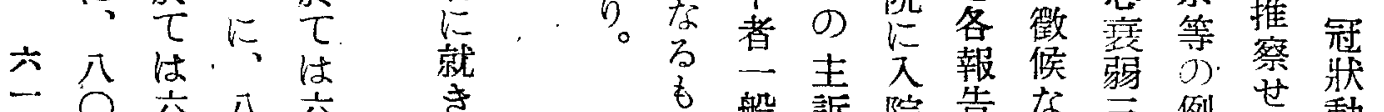
は淮 な 年者り。 以文 㐫它年 全双望 例 文岗

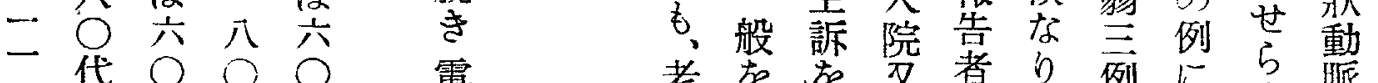

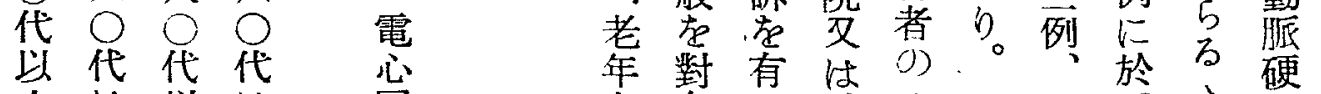
上は以は圖 㸵四六公占 者象古外成灾它虎华

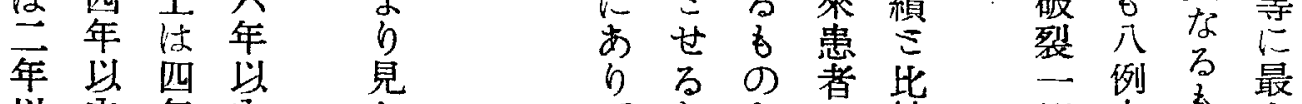
以丙年㐫化

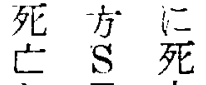

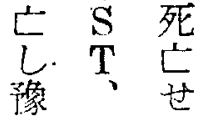
復门る 不變 三 

